\title{
Alleviation of Salt Stress in Upland Rice (Oryza sativa L. ssp. indica cv. Leum Pua) Using Arbuscular Mycorrhizal Fungi Inoculation
}

\section{Rujira Tisarum 1, Cattarin Theerawitaya ${ }^{1}$, Thapanee Samphumphuang ${ }^{1}$, Kanyamin Polispitak ${ }^{2}$, Panarat Thongpoem ${ }^{2}$, Harminder Pal Singh ${ }^{3}$ and Suriyan Cha-um ${ }^{\text {* }}$}

${ }^{1}$ National Center for Genetic Engineering and Biotechnology (BIOTEC), National Science and Technology Development Agency, Khlong Luang, Thailand, ${ }^{2}$ Devision of Biology, Faculty of Science and Technology, Rajamangala University of Technology Thanyaburi, Khlong Hok, Thailand, ${ }^{3}$ Department of Environment Studies, Faculty of Science, Panjab University, Chandigarh, India

Arbuscular mycorrhizal fungi (AMF) symbionts not only promote the growth of host plant but also alleviate abiotic stresses. This study aimed to investigate the putative role of

OPEN ACCESS

Edited by: Collin M. Timm, Johns Hopkins University, United States

Reviewed by: Shaozhen He,

China Agricultural University, China Melissa Cregger, Oak Ridge National Laboratory (DOE), United States

*Correspondence: Suriyan Cha-um suriyanc@biotec.or.th

Specialty section: This article was submitted to Plant Abiotic Stress,

a section of the journal Frontiers in Plant Science

Received: 25 July 2019 Accepted: 09 March 2020 Published: 26 March 2020

Citation:

Tisarum R, Theerawitaya $C$ Samphumphuang T, Polispitak $K$, Thongpoem P, Singh HP and Cha-um S (2020) Alleviation of Salt Stress in Upland Rice (Oryza sativa L. ssp. indica cv. Leum Pua) Using Arbuscular Mycorrhizal Fung Inoculation. Front. Plant Sci. 11:348. doi: 10.3389/fp/s.2020.00348
AMF in salt stress regulation of upland pigmented rice cv. Leum Pua (LP) comparing with Pokkali salt tolerant (positive check). In general, LP is a variety of glutinous rice that contains anthocyanin pigment in the black pericarp, due to which it possesses high antioxidant activities compared to non-pigmented rice. Pot experiment was conducted to evaluate the impact of inoculated AMF, Glomus etunicatum (GE), Glomus geosporum $(\mathrm{GG})$, and Glomus mosseae (GM) strains, in the LP plantlets subjected to 0 (control) or $150 \mathrm{mM} \mathrm{NaCl}$ (salt stress) for 2 weeks in comparison with Pokkali (a salt tolerant rice cultivar), which was maintained as a positive check. Root colonization percentage under $\mathrm{NaCl}$ conditions ranged from 23 to $30 \%$. $\mathrm{Na}^{+}$content in the flag leaf tissues was increased to $18-35 \mathrm{mg} \mathrm{g}^{-1} \mathrm{DW}$ after exposure to $150 \mathrm{mM} \mathrm{NaCl}$ for 14 days in both inoculated and un-inoculated LP plants, whereas Na:K ratio was very low in cv. Pokkali. Interestingly, sucrose content in the flag leaf tissues of un-inoculated LP plants under salt stress was increased significantly by 50 folds over the control as an indicator of salt stress response, whereas it was unchanged in all AMF treatments. Fructose and free proline in GE inoculated plants under salt stress were accumulated over control by 5.75 and 13.59 folds, respectively, for osmotic adjustment of the cell, thereby maintaining the structure and functions of chlorophyll pigments, $F_{v} / F_{m}, \Phi_{P S I I}$, and stomatal function. Shoot height, flag leaf length, number of panicles, panicle length, panicle weight, and 100-grain weight in GE inoculated plants of CV. LP under salt stress were maintained similar to cv. Pokkali. Interestingly, cyanidin-3-glucoside (C3G) and peonidin-3-glucoside (P3G) in the pericarp of cv. LP were regulated by GE inoculation under salt stress conditions. In summary, AMF-inoculation in rice crop is a successful alternative approach to reduce salt toxicity, maintain the yield attributes, and regulate anthocyanins enrichment in the pericarp of grains.

Keywords: AMF-inoculation, anthocyanins, cyanidin-3-glucoside, peonidin-3-glucoside, photosynthetic abilities, salt stress, yield attributes 


\section{INTRODUCTION}

Saline soil affects agricultural productivity in several regions of the world including United States, Argentina, Australia, China, Egypt, India, Iran, Iraq, Pakistan, and Thailand (i.e., an area $>800$ million ha; Rengasamy, 2010). It is estimated that $5 \%$ or 3.85 million ha of the total cultivated area in the world (77 million ha) is affected by salt stress (Sheng et al., 2008), accounting by nearly $50 \%$ of arable land (Wang et al., 2003). By the year 2050, salt affected soil is predicted to be increased up to 16.2 million ha, which may result in food insecurity for world's population (Yadav et al., 2017). In Southeast Asia, 5.8 million ha arable land has been identified as salt affected (Shrestha, 2006). In Thailand, the problem of saline soil is widely distributed in Northeastern region (1.84 million ha), classifying the agricultural areas as slightly, moderately, and severely saltaffected (Arunin and Pongwichian, 2015).

Arbuscular mycorrhizal fungi (AMF) is one of the symbiotic microorganisms that regulate phosphorus $(\mathrm{P})$ content, growth, and yield of the host plant (Gosling et al., 2006). AMF colonizes with root organs of the host plant, and regulates its photosynthetic abilities, growth characteristics, and abiotic stress tolerance (Panneerselvam et al., 2017; Basu et al., 2018; Mbodj et al., 2018). Glomus mosseae (GM), Glomus geosporum (GG), Glomus intraradices, Acaulospora sp., and Scutellospora sp. are AMF species that generally colonize with rice (Gosling et al., 2006; Maiti et al., 2013; Zhang et al., 2014; Tisarum et al., 2019). Previous studies have reported a positive relationship between AMF symbiosis and salt defense mechanisms of the host plants (Ruiz-Lozano and Azcón, 2000). For example, ion homeostasis (influx/efflux), compartmentalization (vacuolar storage), and $\mathrm{Na}^{+}$translocation from root to shoot via apoplastic and/or symplastic routes have been regulated by AMFinoculation (Evelin et al., 2009; Porcel et al., 2012; He and Huang, 2013; Porcel et al., 2016; Yadav et al., 2017; Evelin et al., 2019). Better defense responses in terms of the higher production of free proline, glycine betaine, and soluble sugars in AMF inoculated plants against salt stress have also been reported (Campanelli et al., 2013; Evelin et al., 2013; Garg and Baher, 2013; Talaat and Shawky, 2014). The regulation of proline biosynthesis [pyrroline-5-carboxylate synthetase (P5CS)] and inhibition of proline degradation [proline dehydrogenase $(\mathrm{PDH})]$ are evidently observed when AMF-inoculated plants are exposed to salt stress (Jahromi et al., 2008; Garg and Baher, 2013). Similarly, several antioxidant enzymes, i.e., superoxide dismutase (SOD), catalase (CAT), peroxidase (POD), and ascorbate peroxidase (APX), are upregulated as salt defense responses in AMF inoculated plants under salt stress (Borde et al., 2011; Ruiz-Lozano et al., 2012; Evelin and Kapoor, 2014; Chang et al., 2018).

Rice is an important carbohydrate crop providing a staple food to more than half of the world's population (Khush, 2005). The crop is highly susceptible to salt stress and its productivity declines even at very low concentrations of salt (Zeng and Shannon, 2000; Grattan et al., 2002). Pokkali cultivar of rice is a salt tolerant cultivar, which is used as a positive check in the screening of salt tolerant rice cultivars (Senadhira et al., 2002) and as a parental line in rice breeding programs conducted to develop salt tolerant traits (de Leon et al., 2016). In Thailand, rice is one of the major cultivating crops, and premium rice varieties with high antioxidant capacities, good cooking quality, and better fragrance are produced and exported globally (Vanavichit et al., 2018). Leum Pua (LP) is one such upland cultivar of glutinous rice with black pericarp, good cooking qualities, fine aroma, excellent flavor, high nutritional values, soft texture, and high antioxidant activities (Kerdphol et al., 2015; Nakaew and Sungthong, 2018; Piyawanitpong et al., 2018; Pornputtapitak et al., 2018; Sansenya et al., 2018; Seekhaw et al., 2018). Upland aerobic rice is known for AMF colonization (Maiti et al., 2011); however, studies investigating salt tolerance ability of AMF colonized upland rice are still lacking. Moreover, the physiological adaptations, i.e., photosynthetic pigments, chlorophyll fluorescence, net photosynthetic rate, stomatal conductance and transpiration rate, morphological responses, and yield attributes, in AMF colonized upland rice under salt stress are critically evaluated as major parameters to investigate salt toxicity (Dodd and Pérez-Alfocea, 2012; Hameed et al., 2014; Latef and Miransari, 2014; Muthukumar et al., 2017; Bhattacharjya et al., 2018). Therefore, the objective of this investigation was to evaluate the potential of three Glomus spp. in alleviating the salt stress in pigmented pericarp upland rice (cv. LP) based on physiological and biochemical changes, and yield traits. To the best of our knowledge, this is the first study reporting regulation of salt tolerant abilities in LP using AMF-colonization under salt stress conditions.

\section{MATERIALS AND METHODS}

\section{Plant Material, AMF-Inoculation, and Water Deficit Treatment}

Seeds of pigmented upland rice Cv. "LP (salt sensitive)" and positive check cv. Pokkali (Pok; salt tolerant) were sown in the mixed soil $\left(\mathrm{EC}=2.69 \mathrm{dS} \mathrm{m}^{-1} ; \mathrm{pH}=5.5\right.$; organic matter $=10.36 \%$; total nitrogen $=0.17 \%$; total phosphorus $=0.07 \%$, and total potassium $=1.19 \%)$ for 4 weeks. Healthy seedlings were transplanted into plastic bags containing $2 \mathrm{~kg}$ mixed soil in two groups: (a) sterilized soil without AMF and (b) sterilized soil with AMF species: Glomus etunicatum (GE; synonym Claroideoglomus etunicatum), GG (synonym Funneliformis geosporum), and GM (synonym Funneliformis mosseae) @ $10 \mathrm{~g}$ or 250 spores per plastic bag. Arbuscular mycorrhizal fungus powder was provided by Maejo University, Chiang Mai, Thailand. The powder was inoculated in the soil following the method of Pitaktamrong et al. (2018). The rice plants were grown in a net house under 500-1000 $\mu \mathrm{mol} \mathrm{m} \mathrm{m}^{-2} \mathrm{~s}^{-1}$ photosynthetic photon flux density (PPFD) with a $10 \mathrm{~h} \mathrm{~d}^{-1}$ photoperiod, $35 \pm 2^{\circ} \mathrm{C}$ (day time) $/ 28 \pm 2^{\circ} \mathrm{C}$ (night time) temperature, and $80 \pm 5 \% \mathrm{RH}$ until booting stage. Thereafter, Pok without AMF (Pok), LP without AMF (LP), and LP with AMF (LP + GE; LP + GG; and $\mathrm{LP}+\mathrm{GM}$ ) were exposed to $0 \mathrm{mM} \mathrm{NaCl}$ (control) or $150 \mathrm{mM}$ $\mathrm{NaCl}$ (salt stress) for 14 days. Morphological characters, AMF colonization percentage, inorganic ions $\left(\mathrm{Na}^{+}, \mathrm{K}^{+}\right.$, and $\left.\mathrm{Ca}^{2+}\right)$, total phosphorus, osmotic potential, free proline, soluble sugar, 


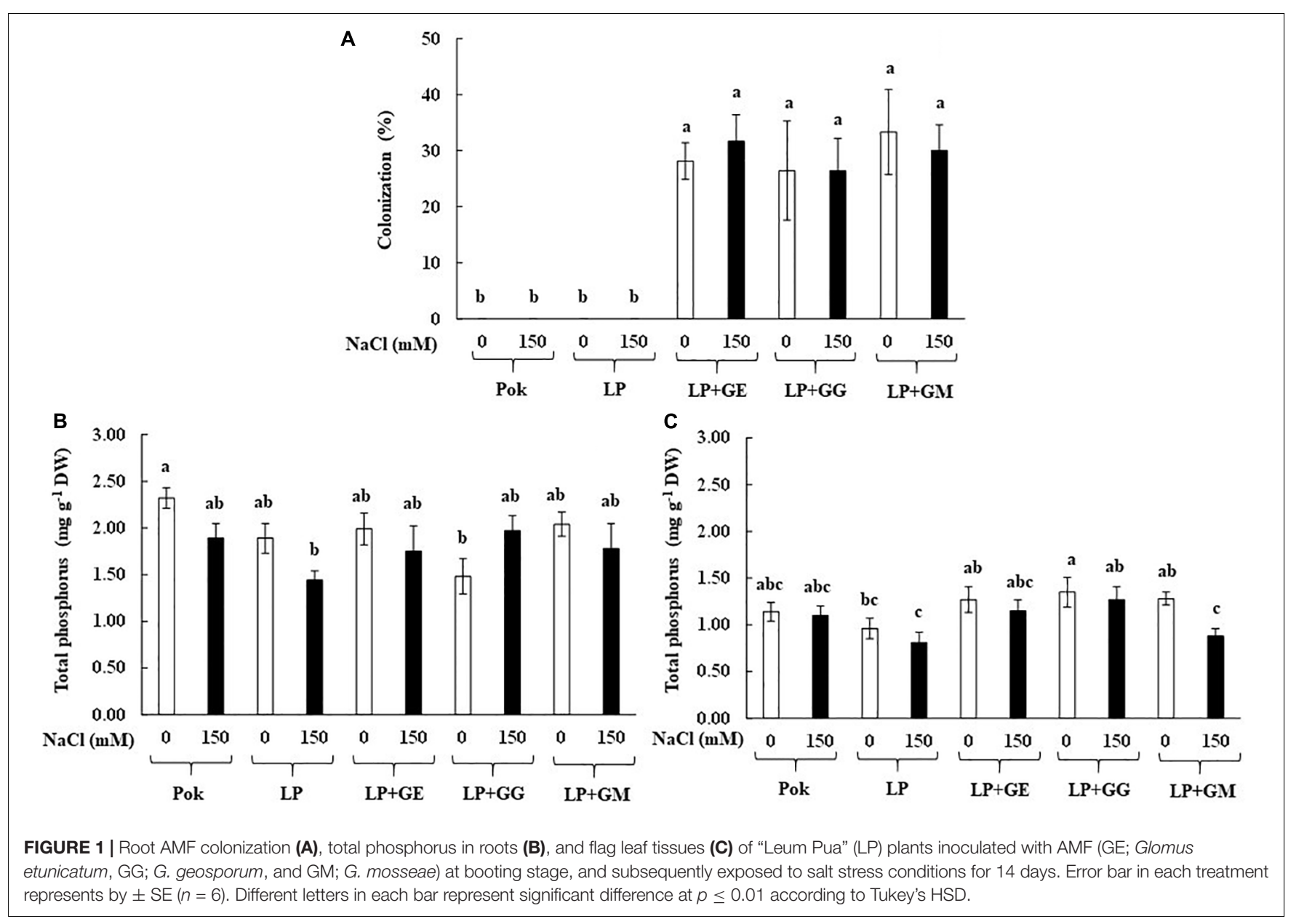

chlorophyll content, chlorophyll fluorescence, net photosynthetic rate, stomatal conductance, and transpiration rate were measured in these 10 sets of observations. In addition, the grain yield traits, number of panicles, panicle length, grain fertility percentage, panicle weight, total grain yield per clump, 100-grain weight, and anthocyanin content of cyanidin-3-glucoside (C3G) and peonidin-3-glucoside (P3G) were evaluated in the pericarp of LP rice at the time of harvest.

\section{AMF Colonization Assay}

Fresh roots $(3.0 \pm 0.5 \mathrm{~cm}$ in length) were collected from each set of observations, washed with distilled water, cut into $1.0 \mathrm{~cm}$ length and kept in 60\% ethanol (used as a storage solution). Roots were washed thrice with distilled water, transferred to $10 \% \mathrm{KOH}$, and incubated at $95^{\circ} \mathrm{C}$ for $30 \mathrm{~min}$. Cleaned roots were again washed with distilled water and stained using $0.05 \%(w / v)$ Trypan blue for $15 \mathrm{~min}$. AMF-colonization in the roots was observed under light microscope (Zeiss, Germany) to count the arbuscules, vesicles, and mycorrhizal hyphae (Supplementary Figure S1), according to the method of Brundrett et al. (1996).

\section{Plant Biochemical Analysis}

$\mathrm{Na}^{+}, \mathrm{K}^{+}$, and $\mathrm{Ca}^{2+}$ were assayed following the modified method of Tanaka et al. (1999) and Hossain et al. (2006). In brief, flag leaf tissues were collected and washed by deionized water to remove surface contaminating ions. The tissue was ground into a powder in liquid nitrogen, extracted with boiling distilled water, and centrifuged at $10,000 \times g$ for $10 \mathrm{~min}$. The supernatant was filtered through a $0.45 \mu \mathrm{m}$ membrane filter (VertiPure ${ }^{\mathrm{TM}}$, Vertical ${ }^{\circledR}$ ). Cellular $\mathrm{Na}^{+}, \mathrm{K}^{+}$, and $\mathrm{Ca}^{2+}$ concentrations were determined using Waters HPLC coupled with 432 Conductivity Detector and WATER IC-PACK ${ }^{\mathrm{TM}}$ ion-exclusion column (Waters Associates, Millford, MA, United States). Mobile phase, a mixed solution of $0.012 \mu \mathrm{M}$ nitric acid and $71.73 \mu \mathrm{M}$ Na-EDTA (ethylene diamine tetraacetic acid disodium salt dehydrate) in deionized water, was used at $0.6 \mathrm{~mL} \mathrm{~min}^{-1}$ flow rate. $\mathrm{Na}^{+}, \mathrm{K}^{+}$, and $\mathrm{Ca}^{2+}$ (Sigma, United States) were used as standards.

Available phosphorus (P) was extracted and determined spectrophotometrically as blue molybdate-phosphate complexes under partial reduction with ascorbic acid (Jackson, 1958). Briefly, $100 \mathrm{mg}$ of dried root and flag leaf samples in each treatment were ground, transferred to $1 \mathrm{~mL}$ digestion mixture (0.42 $\mathrm{g} \mathrm{Se}, 14 \mathrm{~g} \mathrm{LiSO} \cdot 2 \mathrm{H}_{2} \mathrm{O}$ added to $350 \mathrm{~mL} \mathrm{H}_{2} \mathrm{O}_{2}$, and $420 \mathrm{~mL} \mathrm{H}_{2} \mathrm{SO}_{4}$ ), and then placed on the hot plate (gradually increased from 50 to $150^{\circ} \mathrm{C}$ ) until the mixture turned back. Five-hundred microliters of $72 \% \mathrm{HClO}_{4}$ was added to each sample and heated until the material became colorless. After cooling, the samples were diluted with equal 

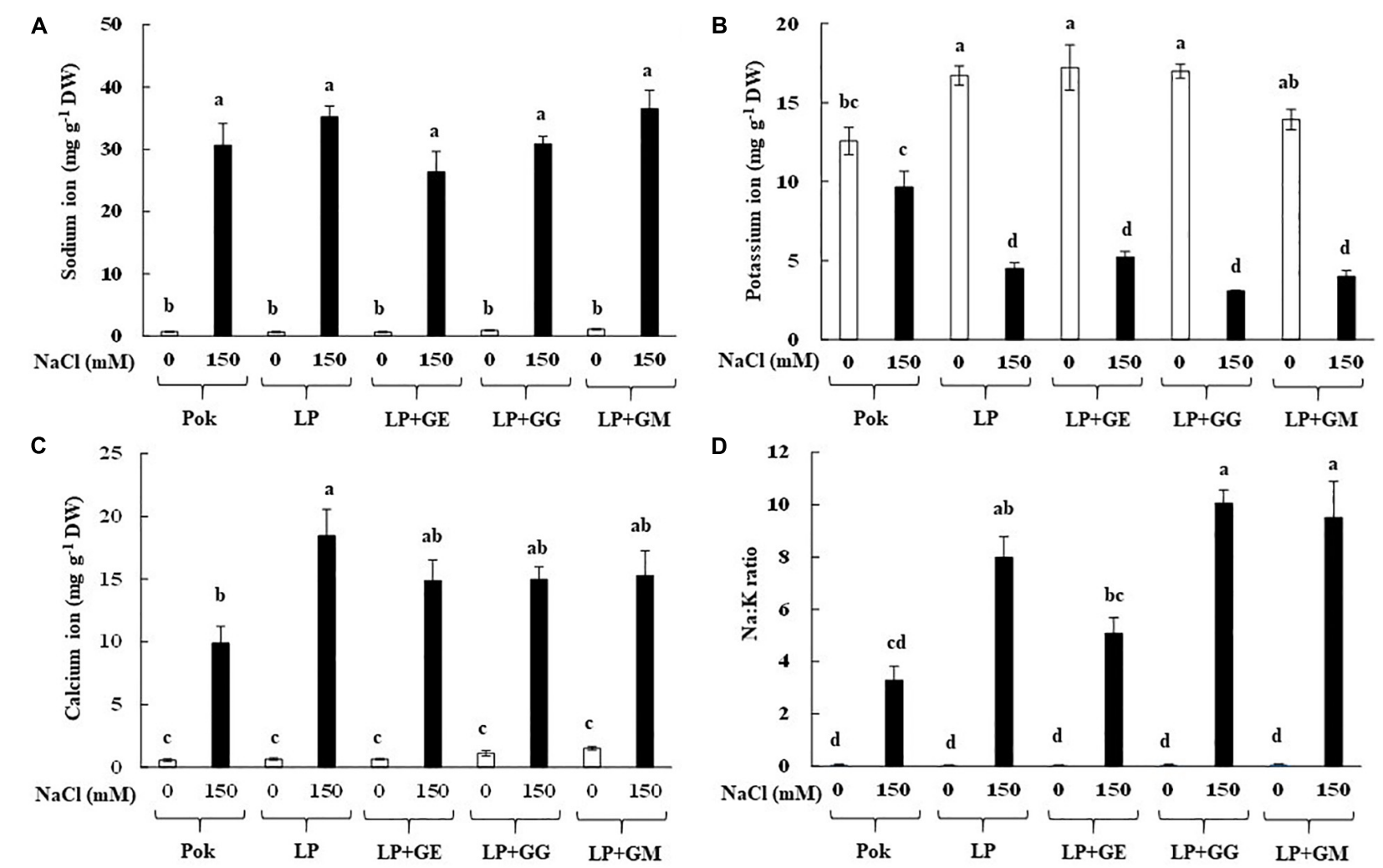

FIGURE 2 | Sodium (A), potassium (B), calcium (C) ions, and Na:K ratio (D) in flag leaf tissues of "Leum Pua" (LP) plants inoculated with AMF (GE; Glomus etunicatum, GG; G. geosporum, and GM; G. mosseae) at booting stage, and subsequently exposed to salt stress conditions for 14 days. Error bar in each treatment represents by \pm SE $(n=6)$. Different letters in each bar represent significant difference at $p \leq 0.01$ according to Tukey's HSD.

volume of $\mathrm{HClO}_{4}$, filtered (Whatman \#42, United Kingdom) and then mixed with $0.5 \mathrm{~mL}$ of Barton's reagent $[25 \mathrm{~g}$ ammonium molybdate $(400 \mathrm{~mL}), 1.25 \mathrm{~g}$ ammonium metavanadate $(350 \mathrm{~mL})$, and $\left.\mathrm{HNO}_{3}(250 \mathrm{~mL})\right]$ for $10 \mathrm{~min}$. Total P (mg g ${ }^{-1}$ DW) was measured at $420 \mathrm{~nm}$ by UVspectrophotometer (HACH DR/4000; Model 48,000, HACH Company, Loveland, $\mathrm{CO}$, United States) using $\mathrm{KH}_{2} \mathrm{PO}_{4}$ as a calibration standard.

Free proline in the flag leaf tissues was extracted and analyzed according to the method of Bates et al. (1973). Fifty milligrams of fresh material was ground with liquid nitrogen in a mortar. The homogenate powder was mixed with $1 \mathrm{~mL}$ of aqueous sulfosalicylic acid $(3 \%, w / v)$ and filtered through filter paper (Whatman\#1, United Kingdom). The extracted solution was reacted with an equal volume of glacial acetic acid and ninhydrin reagent $(1.25 \mathrm{mg}$ ninhydrin in $30 \mathrm{~mL}$ glacial acetic acid and $20 \mathrm{~mL}$ $6 \mathrm{M} \mathrm{H}_{3} \mathrm{PO}_{4}$ ) and incubated at $95^{\circ} \mathrm{C}$ for $1 \mathrm{~h}$. The reaction was terminated by placing the container in an ice bath. The reaction mixture was mixed vigorously with $2 \mathrm{~mL}$ of toluene. After cooling to $25^{\circ} \mathrm{C}$, the chromophore was measured at $520 \mathrm{~nm}$ by UV-Vis spectrophotometer using L-proline as a calibration standard.

Soluble sugars (sucrose, glucose, and fructose) in the flag leaf tissues were assayed following the method of Karkacier et al. (2003). In brief, $50 \mathrm{mg}$ of flag leaf sample was ground in a mortar with liquid nitrogen. One milliliter of nanopure water was added and centrifuged at $10,000 \times g$ for $15 \mathrm{~min}$. The supernatant was collected and filtered through a $0.45 \mu \mathrm{m}$ membrane filter (VertiPure $^{\mathrm{TM}}$, Vertical $\left.^{\circledR}\right)$. Twenty microliters of the filtrate was

TABLE 1 | Sucrose, glucose and fructose contents in "Leum Pua" (LP) plants inoculated with AMF (GE; Glomus etunicatum, GG; G. geosporum, and GM; G. mosseae) of rice cv. at booting stage, and subsequently exposed to salt stress conditions for 14 days.

\begin{tabular}{|c|c|c|c|c|}
\hline Treatment & $\begin{array}{l}\mathrm{NaCl} \\
(\mathrm{mM})\end{array}$ & $\begin{array}{l}\text { Sucrose (mg } \\
\mathbf{g}^{-1} \text { DW) }\end{array}$ & $\begin{array}{l}\text { Glucose (mg } \\
\mathbf{g}^{-1} \text { DW) }\end{array}$ & $\begin{array}{c}\text { Fructose (mg } \\
\left.\mathrm{g}^{-1} \mathrm{DW}\right)\end{array}$ \\
\hline \multirow[t]{2}{*}{ Pok } & 0 & $4.67 b$ & $88.03 b$ & 139.70ab \\
\hline & 150 & $23.21 b$ & $104.97 a b$ & $159.16 \mathrm{ab}$ \\
\hline \multirow[t]{2}{*}{ LP } & 0 & $2.36 b$ & $97.77 b$ & $112.32 \mathrm{bc}$ \\
\hline & 150 & $146.72 a$ & 115.91a & $166.78 \mathrm{a}$ \\
\hline \multirow[t]{2}{*}{$\mathrm{LP}+\mathrm{GE}$} & 0 & $14.81 b$ & $53.80 c$ & $6.72 d$ \\
\hline & 150 & $26.52 b$ & $58.31 c$ & $91.34 \mathrm{bc}$ \\
\hline \multirow[t]{2}{*}{$L P+G G$} & 0 & $44.94 b$ & $47.29 c$ & $77.46 c$ \\
\hline & 150 & $52.31 b$ & $88.02 b$ & $113.11 b c$ \\
\hline \multirow[t]{2}{*}{$\mathrm{LP}+\mathrm{GM}$} & 0 & $50.27 \mathrm{~b}$ & $77.76 \mathrm{bc}$ & $121.53 b$ \\
\hline & 150 & $55.25 b$ & $96.13 b$ & $120.41 b$ \\
\hline Significant level & & $\star \star$ & $\star \star$ & $\star *$ \\
\hline
\end{tabular}

Pok: Pokkali, salt tolerant genotype, positive check. ${ }^{* *}$ represents highly significant difference at $p \leq 0.01$. Different letters in each column show significant difference at $p \leq 0.01$ according to Tukey's HSD. 

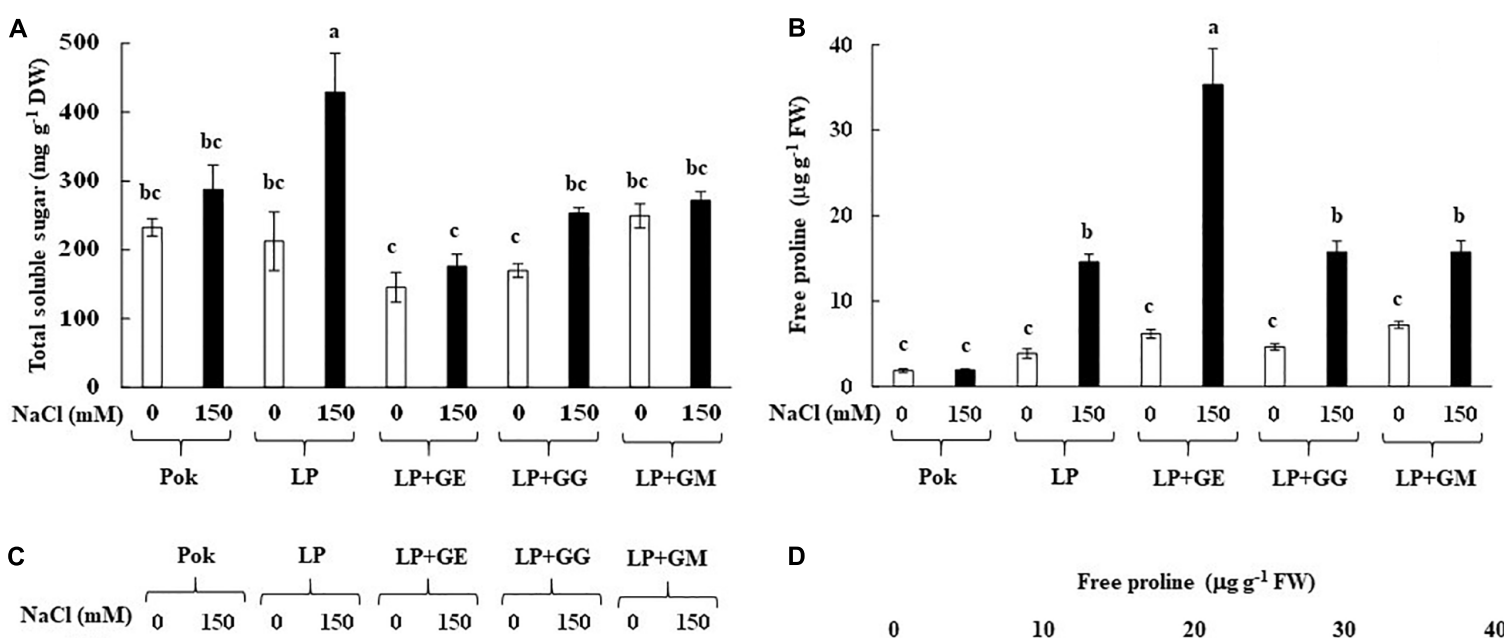

D
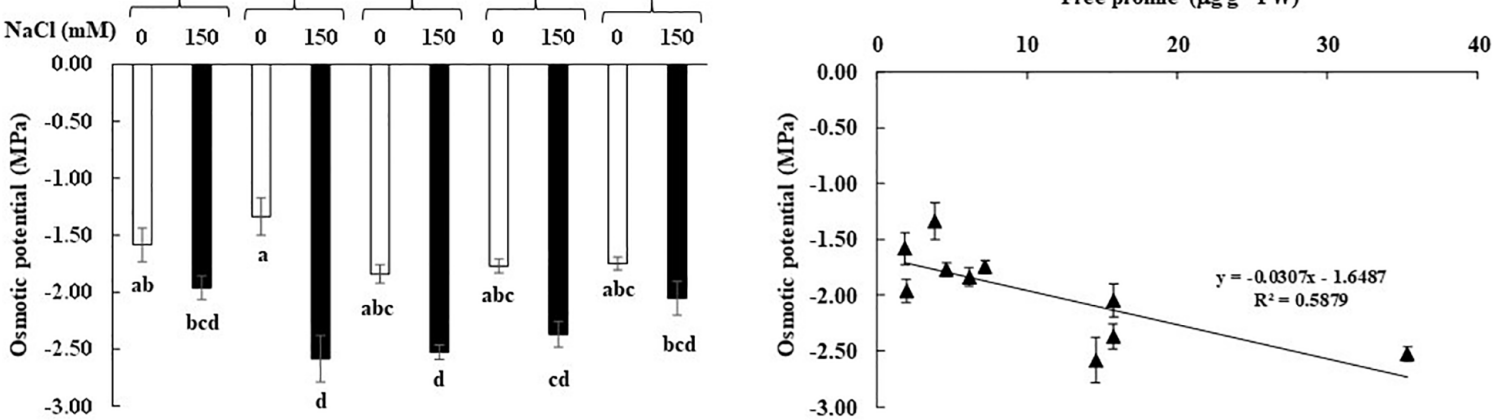

FIGURE 3 | Total soluble sugar (A), free proline (B), osmotic potential in flag leaf (C), and relationship between free proline and osmotic potential in flag leaf (D) of "Leum Pua" (LP) plants inoculated with AMF (GE; Glomus etunicatum, GG; G. geosporum, and GM; G. mosseae) at booting stage, and subsequently exposed to salt stress conditions for 14 days. Error bar in each treatment represents by $\pm S E(n=6)$. Different letters in each bar represent significant difference at $p \leq 0.01$ according to Tukey's HSD.

injected into a Waters HPLC equipped with a MetaCarb 87C column and a guard column. Deionized water was used as the mobile phase at a flow rate of $0.5 \mathrm{~mL} \mathrm{~min}^{-1}$. The online detection was performed using a Waters 410 differential refractrometer detector and the data were analyzed by Empower ${ }^{\circledR}$ software. Sucrose, glucose, and fructose (Fluka, United States) were used as the standards.

Total anthocyanins (C3G and P3G) were assayed following the method of Chandra et al. (2001). Hand-dehusked seeds (2 g) were weighed and transferred in capped glass vials and then $1.5 \mathrm{~mL}$ of $1 \% \mathrm{HCl}$ in methanol were added (Supplementary Figure S2). Extracted solution was vortexed and kept in the dark on the shaker $(150 \mathrm{r} / \mathrm{min})$ for $12 \mathrm{~h}$ in the cold room $\left(8^{\circ} \mathrm{C}\right)$. Supernatant was collected and filtered through a $0.45 \mu \mathrm{m}$ PTFE filter (VertiPure, Vertical Chromatography). Each sample was analyzed by Waters HPLC equipped with a Waters 2998 photodiode array detector set at $520 \mathrm{~nm}$, and fitted with an ODS $\mathrm{C}_{18}$ Hypersil column $(250 \mathrm{~mm} \times 4.6 \mathrm{~mm}$; $5 \mu \mathrm{m}$, Thermo Fisher Scientific Inc., CA, United States). The mobile phase comprised of: Solvent A $(0.5 \%$ aqueous phosphoric acid, $v / v)$, and solvent B (water/acetonitrile/glacial acetic acid/phosphoric acid, 50: 48.5: 1: 0.5, $v / v / v / v)$ used as following gradient: $0 \mathrm{~min}, 20 \% \mathrm{~B}$ (i.e., $80 \%$ solvent $\mathrm{A}$ and $20 \%$ solvent $\mathrm{B}$ ); $1-$ $26 \mathrm{~min}, 60 \% \mathrm{~B}, 27-30 \mathrm{~min}, 20 \% \mathrm{~B}, 31-35 \mathrm{~min}, 20 \% \mathrm{~B}(80 \%)$.

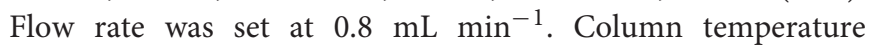

was set at $30^{\circ} \mathrm{C}$ and injection volume was $20 \mu \mathrm{L}$. C3G and P3G (Sigma-Aldrich, United States) were injected as standards (Supplementary Figure S3).

\section{Plant Physiological Assay}

Osmotic potential in the flag leaf of "LP" rice was measured according to Lanfermeijer et al. (1991). In brief, $100 \mathrm{mg}$ of fresh tissue were chopped into small pieces, transferred to $1.5 \mathrm{~mL}$ micro tube, and then crushed using a glass rod. The $20 \mu \mathrm{L}$ of extracted solution was dropped directly onto a filter paper in an osmometer chamber (5520 Vapro ${ }^{\circledR}$, Wescor, UT, United States) and subsequently, the data were collected. Then, the osmolarity $(\mathrm{mmol} \mathrm{kg}-1)$ was converted to osmotic potential $(\mathrm{MPa})$ using conversion factor of osmotic potential measurement.

Chlorophyll a $\left(\mathrm{Chl}_{\mathrm{a}}\right)$, chlorophyll $\mathrm{b}\left(\mathrm{Chl}_{\mathrm{b}}\right)$, and total chlorophyll (TC) in the flag leaf tissues were analyzed according to the method of Shabala et al. (1998), whereas total carotenoid $\left(\mathrm{C}_{\mathrm{x}+\mathrm{c}}\right)$ content was assayed following the method of Lichtenthaler (1987). One hundred milligrams of leaf tissue was homogenized in glass vials using $10 \mathrm{~mL}$ of $99.5 \%$ acetone and blended using a homogenizer (model T25 Ultra Turrax ${ }^{\circledR}$, IKA, Malaysia). The glass vials were sealed with Parafilm ${ }^{\circledR}$ to prevent evaporation, and then stored at $4^{\circ} \mathrm{C}$ for $48 \mathrm{~h}$. $\mathrm{Chl}_{\mathrm{a}}$ and $\mathrm{Chl}_{\mathrm{b}}$ concentrations were measured at 662 and $644 \mathrm{~nm}$, whereas 
$\mathrm{C}_{\mathrm{x}+\mathrm{c}}$ concentration was measured at $470 \mathrm{~nm}$ using UV-Vis spectrophotometer against acetone $(99.5 \%)$ as a blank.

Chlorophyll fluorescence emission was measured from the adaxial surface of flag leaf using a fluorescence monitoring system (model FMS 2; Hansatech Instruments Ltd., Norfolk, United Kingdom) in the pulse amplitude modulation mode (Loggini et al., 1999). A leaf, kept in dark for $30 \mathrm{~min}$, was initially exposed to the modulated measuring beam of far-red light (LED source) with typical peak at wavelength $735 \mathrm{~nm}$. Original $\left(\mathrm{F}_{0}\right)$ and maximum $\left(\mathrm{F}_{\mathrm{m}}\right)$ fluorescence yields were measured under weak modulated red light $\left(<85 \mu \mathrm{mol} \mathrm{m} \mathrm{m}^{-2} \mathrm{~s}^{-1}\right)$ with $1.6 \mathrm{~s}$ pulses of saturating light $\left(>1500 \mu \mathrm{mol} \mathrm{m} \mathrm{m}^{-2} \mathrm{~s}^{-1}\right.$ PPFD) and calculated using FMS software for Windows ${ }^{\circledR}$. The variable fluorescence yield $\left(\mathrm{F}_{\mathrm{v}}\right)$ was calculated using the equation: $\mathrm{F}_{\mathrm{v}}=\mathrm{F}_{\mathrm{m}}-\mathrm{F}_{0}$. The ratio of variable to maximum fluorescence $\left(\mathrm{F}_{\mathrm{v}} / \mathrm{F}_{\mathrm{m}}\right)$ was calculated as the maximum quantum yield of PSII photochemistry. The photon yield of PSII ( $\Phi_{\text {PSII }}$ ) in the light was calculated as: $\mathrm{F}_{\text {PSII }}=\left(\mathrm{F}_{\mathrm{m}}{ }^{\prime}-\mathrm{F}\right) / \mathrm{F}_{\mathrm{m}}{ }^{\prime}$ after $45 \mathrm{~s}$ of illumination, when steady state was achieved (Maxwell and Johnson, 2000).

Net photosynthetic rate $\left(\mathrm{P}_{\mathrm{n}} ; \mu \mathrm{mol} \mathrm{m} \mathrm{m}^{-2} \mathrm{~s}^{-1}\right)$, transpiration rate $\left(\mathrm{E} ; \mathrm{mmol} \mathrm{H}_{2} \mathrm{O} \mathrm{m} \mathrm{m}^{-2} \mathrm{~s}^{-1}\right)$, and stomatal conductance $\left(\mathrm{g}_{\mathrm{s}}\right.$; mmol m${ }^{-2} \mathrm{~s}^{-1}$ ) were measured using a Portable Photosynthesis System fitted with an Infra-red Gas Analyzer (IRGA, Model LI 6400, LI-COR ${ }^{\circledR}$ Inc., Lincoln, NE, United States). All parameters were measured continuously by monitoring the content of the air entering and exiting in the IRGA headspace chamber, according to Cha-um et al. (2007).

\section{Plant Morphological Characterization and Yield Traits}

Shoot height, number of leaves, leaf length, leaf width, and number of tillers were measured in LP rice at booting stage (Supplementary Figure S4). Total grain yield, number of

TABLE 2 | Chlorophyll a $\left(\mathrm{Ch}_{\mathrm{a}}\right)$, chlorophyll b $\left(\mathrm{Ch} \mathrm{l}_{\mathrm{b}}\right)$, and total carotenoids $\left(\mathrm{C}_{\mathrm{x}+\mathrm{c}}\right)$ contents in "Leum Pua" (LP) plants inoculated with AMF (GE; Glomus etunicatum, GG; G. geosporum, and GM; G. mosseae) of rice cv. at booting stage, and subsequently exposed to salt stress conditions for 14 days.

\begin{tabular}{|c|c|c|c|c|}
\hline Treatment & $\begin{array}{l}\mathrm{NaCl} \\
(\mathrm{mM})\end{array}$ & $\begin{array}{l}\text { Chlorophyll a } \\
\left(\mu \mathrm{g} \mathrm{g}^{-1} \mathrm{FW}\right)\end{array}$ & $\begin{array}{l}\text { Chlorophyll b } \\
\left(\mu \mathrm{g} \mathrm{g}^{-1} \mathrm{FW}\right)\end{array}$ & $\begin{array}{c}\text { Total } \\
\text { carotenoids } \\
\left(\mu \mathrm{g} \mathrm{g}^{-1} \mathrm{FW}\right)\end{array}$ \\
\hline \multirow[t]{2}{*}{ Pok } & 0 & $63.49 \mathrm{c}$ & $52.88 \mathrm{c}$ & $7.46 \mathrm{bc}$ \\
\hline & 150 & $58.75 c$ & $51.26 \mathrm{c}$ & $7.05 \mathrm{bc}$ \\
\hline \multirow[t]{2}{*}{ LP } & 0 & $233.70 a$ & $118.72 \mathrm{a}$ & $12.60 a b$ \\
\hline & 150 & $82.99 c$ & $76.71 \mathrm{bc}$ & $6.24 c$ \\
\hline \multirow[t]{2}{*}{$\mathrm{LP}+\mathrm{GE}$} & 0 & 209.94ab & $133.76 a$ & $16.66 a$ \\
\hline & 150 & $98.88 \mathrm{bc}$ & 88.79abc & 13.39ab \\
\hline \multirow[t]{2}{*}{$L P+G G$} & 0 & $214.61 \mathrm{ab}$ & $133.82 a$ & $16.89 a$ \\
\hline & 150 & $70.35 c$ & $66.22 \mathrm{c}$ & $6.73 c$ \\
\hline \multirow[t]{2}{*}{$L P+G M$} & 0 & $217.01 \mathrm{ab}$ & $135.36 a$ & $19.00 \mathrm{a}$ \\
\hline & 150 & $72.69 c$ & $68.10 \mathrm{c}$ & $7.91 b c$ \\
\hline Significant level & & $\star \star$ & $\star \star$ & $\star \star$ \\
\hline
\end{tabular}

panicles, panicle dry weight, panicle length, seed fertility, and 100 -grain weight were also evaluated at harvesting stage.

\section{Statistical Analysis}

The experiment was arranged as Completely Randomized Design (CRD) with six biological replicates $(n=6)$ in each treatment. The mean values obtained from 10 set of observations were compared using Tukey's HSD and analyzed by SPSS software (version 11.5 for Window ${ }^{\circledR}$ ).

\section{RESULTS AND DISCUSSION}

\section{AMF Colonization and Total P Assay}

Arbuscular mycorrhizal fungi colonization percentage in the root tissues of rice cv. LP inoculated with GE, GG, and GM was found to be $>26 \%$, irrespective of the salt treatment (Figure 1A). Total $\mathrm{P}$ content in the root tissues was greater than that of leaf tissues. Under salt stress, total $\mathrm{P}$ content in the root tissues was nearly same in the inoculated and un-inoculated plants. In addition, $\mathrm{P}$ content in the root tissues of rice cv. Pokkali (Pok) under control was greater than cv. LP as well as LP + GG (Figure 1B). On the other hand, $\mathrm{P}$ content in leaf tissues of LP + GG $(1.35 \mathrm{mg}$ $\left.\mathrm{g}^{-1} \mathrm{DW}\right)$ was greater than LP $\left(0.81 \mathrm{mg} \mathrm{g}^{-1} \mathrm{DW}\right)$ by 1.67 folds (Figure 1C). Moreover, P content in the leaf tissues of LP + GM under salt stress declined by $31.25 \%$ over the control.

In the present study, root colonization of AMF inoculated plants was evidently demonstrated in both control and salt stress conditions, whereas it was undetected in un-inoculated plants. As per a previous report inoculation of AM fungus isolated from salt affected soil (Cabo de Gata Natural Park, Spain) showed a positive relation between degree of salt treatments (75 and $150 \mathrm{mM} \mathrm{NaCl}$ ) and root colonization, and also increased the total P in both shoots and roots (Porcel et al., 2016). Interestingly, root colonization of Rhizophagus intraradices (collected), C. etunicatum, and Septoglomus constrictum was alleviated by salt-treated ( 66 and $100 \mathrm{mM} \mathrm{NaCl}$ ) maize plants (Estrada et al., 2013a). In contrast, when Glomus spp. collected from rhizosphere of maize plants was inoculated in wheat plants, and subsequently exposed to salt stress, a decline in AM-fungal colonization, especially at high salinity levels (4.7 and 9.4 dS $\mathrm{m}^{-1}$ ) was observed (Talaat and Shawky, 2014). Similarly, in alfalfa, colonization percentage of AMF (Glomus viscosum) was sharply declined, in relation to the degree of salt treatments (100-150 mM NaCl) (Campanelli et al., 2013). Colonization percentage of $R$. intraradices, Massilia sp. RK4, and their mixtures (collected from rhizosphere of the Phragmites sp., Saemangeum reclamation land, South Korea) in maize plants was significantly dropped when subjected to 40 and $80 \mathrm{mM} \mathrm{NaCl}$ for 22 days (Krishnamoorthy et al., 2016). In Leymus chinensis seedlings, AM root colonization was only detected in AMF inoculation under salt stress (100-200 mM NaCl), whereas it was undetected in un-inoculated plants (Lin et al., 2017).

\section{$\mathrm{Na}^{+}, \mathrm{K}^{+}, \mathrm{Ca}^{2+}$, and $\mathrm{Na}$ : K Ratio}

$\mathrm{Na}^{+}$levels in the flag leaf tissues of rice cvs. Pok $\left(30.66 \mathrm{mg} \mathrm{g}^{-1}\right.$ DW) and LP (35.20 $\left.\mathrm{mg} \mathrm{g}^{-1} \mathrm{DW}\right)$ were increased in response 

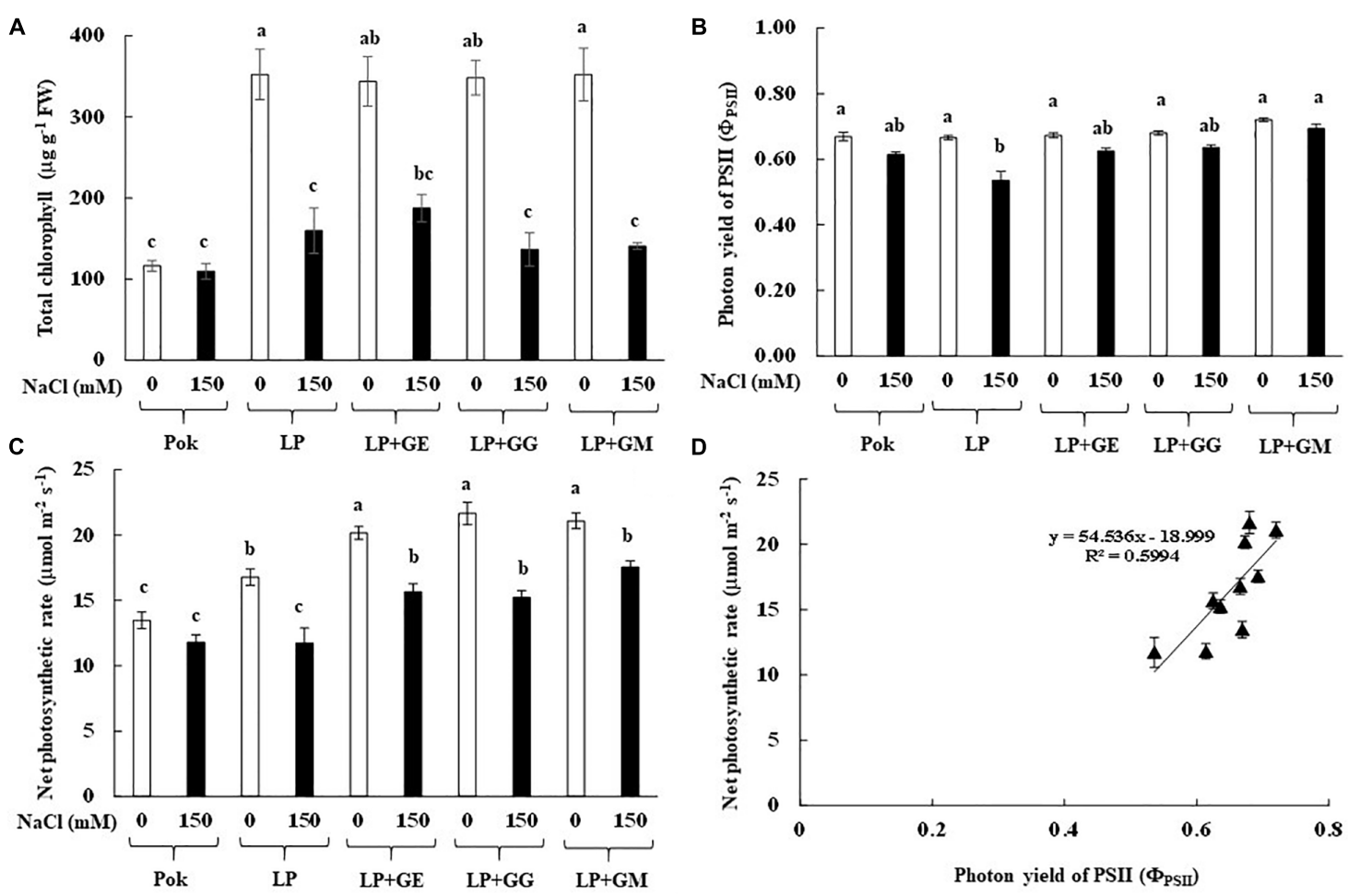

FIGURE 4 | Total chlorophyll content (A), photon yield of PSII (B), net photosynthetic rate (C), and relationship between photon yield of PSII and net photosynthetic rate in flag leaf (D) of "Leum Pua" (LP) plants inoculated with AMF (GE; Glomus etunicatum, GG; G. geosporum, and GM; G. mosseae) at booting stage, and subsequently exposed to salt stress conditions for 14 days. Error bar in each treatment represents by \pm SE $(n=6)$. Different letters in each bar represent significant difference at $p \leq 0.01$ according to Tukey's HSD.

to $150 \mathrm{mM} \mathrm{NaCl}$ treatment over the control by 43.20 and 52.50 folds, respectively (Figure 2A). Compared to control, 32.9040.60 folds increase in $\mathrm{Na}^{+}$level in AMF inoculated plants (GE, GG, and GM) in LP under salt stress was observed. Interestingly, $\mathrm{K}^{+}$in LP was significantly decreased when plants, both with and without $\mathrm{AMF}$, were exposed to $150 \mathrm{mM} \mathrm{NaCl}$ salt stress for 14 days, while it was maintained in cv. Pok (Figure 2B). $\mathrm{Ca}^{2+}$ was found to be $18.47 \mathrm{mg} \mathrm{g}^{-1} \mathrm{DW}$ in LP without AMF under salt stress (28.4 folds over control), whereas it was $9.89 \mathrm{mg} \mathrm{g}^{-1}$ DW in Pok under salt stress (17.7 folds over control) (Figure 2C). $\mathrm{Na}$ K ratio in salt stressed LP plants, both with and without AMF, was significantly increased; however, it was maintained in $\mathrm{cV}$. Pok (Figure 2D).

$\mathrm{Na}^{+}$and $\mathrm{Ca}^{2+}$ were accumulated (by $>10$ folds) in the flag leaf tissues of rice cvs. Pok and LP under $150 \mathrm{mM} \mathrm{NaCl}$ for 14 days irrespective of AMF-inoculation, whereas $\mathrm{K}^{+}$in LP declined, leading to greater $\mathrm{Na}^{+}: \mathrm{K}^{+}$ratio. Therefore, $\mathrm{Na}^{+}$ enrichment in LP with GE, GG, or GM was lower than that of LP without AMF inoculation. $\mathrm{Na}^{+}$in AMF (R. intraradices, Massilia sp. RK4, and their mixtures) inoculated maize (cv. Shrunken-2) plants grown under $40 \mathrm{mM} \mathrm{NaCl}$ for 17 days was lower than that in the plants without AMF-inoculation (Krishnamoorthy et al., 2016). Similarly, $\mathrm{Na}^{+}$in shoots of AMF (R. intraradices, C. etunicatum, and $S$. constrictum) inoculated maize plants under 66 and $100 \mathrm{mM} \mathrm{NaCl}$ was lower than that in the plants without AMF (Estrada et al., 2013a). In wheat cv. Henta, $\mathrm{Na}^{+}$in shoots of AMF (GM and Glomus deserticola) inoculated plants was significantly lesser than in un-inoculated plants and Gigaspora gergaria inoculated plants (Abdel-Fattah and Asrar, 2012). In

TABLE 3 | Maximum quantum yield of PSII $\left(F_{v} / F_{m}\right)$, stomatal conductance $\left(g_{s}\right)$, and transpiration rate (E) in AMF-inoculated plants (GE; Glomus etunicatum, GG; G. geosporum, and GM; G. mosseae) of rice cv. "Leum Pua" (LP) at booting stage subsequently exposed to salt stress conditions for 14 days.

\begin{tabular}{|c|c|c|c|c|}
\hline Treatment & $\begin{array}{l}\mathrm{NaCl} \\
(\mathrm{mM})\end{array}$ & $F_{v} / F_{m}$ & $\begin{array}{c}\mathrm{gs}_{\mathrm{s}}(\mathrm{mmol} \\
\mathrm{H}_{2} \mathrm{O} \\
\left.\mathrm{m}^{-2} \mathrm{~s}^{-1}\right)\end{array}$ & $\begin{array}{c}E(\mathrm{mmol} \\
\mathrm{H}_{2} \mathrm{O} \\
\left.\mathrm{m}^{-2} \mathrm{~s}^{-1}\right)\end{array}$ \\
\hline \multirow[t]{2}{*}{ Pok } & 0 & $0.865 a$ & $0.42 a$ & $4.28 \mathrm{ab}$ \\
\hline & 150 & $0.793 a b$ & $0.32 a b$ & $3.60 b$ \\
\hline \multirow[t]{2}{*}{ LP } & 0 & $0.839 a b$ & $0.29 b$ & $3.98 a b$ \\
\hline & 150 & $0.629 c$ & $0.20 \mathrm{c}$ & $2.83 \mathrm{c}$ \\
\hline \multirow[t]{2}{*}{$\mathrm{LP}+\mathrm{GE}$} & 0 & $0.858 a$ & $0.40 a b$ & $4.98 a$ \\
\hline & 150 & $0.818 a b$ & $0.32 \mathrm{ab}$ & 4.13ab \\
\hline \multirow[t]{2}{*}{$L P+G G$} & 0 & $0.842 \mathrm{ab}$ & $0.39 a b$ & $4.77 a$ \\
\hline & 150 & $0.812 \mathrm{ab}$ & $0.32 \mathrm{ab}$ & $4.09 a b$ \\
\hline \multirow[t]{2}{*}{$\mathrm{LP}+\mathrm{GM}$} & 0 & $0.844 a b$ & $0.35 a b$ & $5.01 a$ \\
\hline & 150 & $0.818 a b$ & $0.31 \mathrm{ab}$ & $4.20 a b$ \\
\hline Significant ley & & $\star \star \star$ & $\star \star$ & 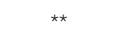 \\
\hline
\end{tabular}

Pok: Pokkali, salt tolerant genotype, positive check. ${ }^{* *}$ represents highly significant difference at $p \leq 0.01$. Different letters in each column show significant difference at $p \leq 0.01$ according to Tukey's HSD. 


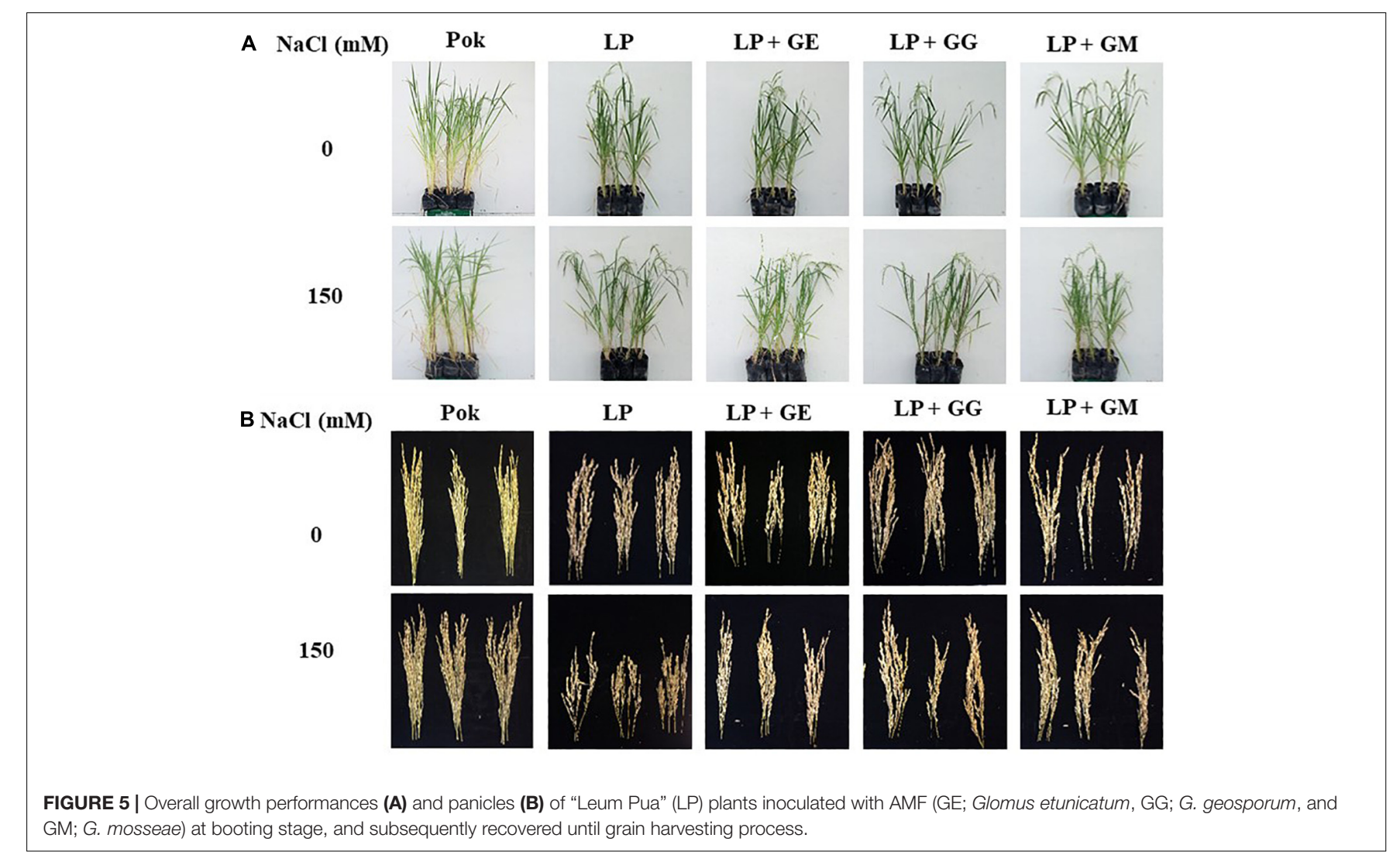

alfalfa cv. icon, low levels of $\mathrm{Na}^{+}$in AMF inoculated plants were demonstrated when compared with the control (Campanelli et al., 2013). In citrus (red tangerine) seedlings, $\mathrm{Na}^{+}$enrichment is generally antagonist with $\mathrm{K}^{+}$when subjected to $100 \mathrm{mM}$ $\mathrm{NaCl}$ for 60 days and also, $\mathrm{Na}^{+}$in AMF inoculated plants (GM and Paraglomus occultum) was significantly lower than in uninoculated plants (Wu et al., 2010). Moreover, $\mathrm{Na}^{+}$in AMF inoculated wheat cv. Sids 1 was unchanged, whereas it was increased in cv. Giza 168 over AMF un-inoculated plants, in response to the degree of salinity levels (Talaat and Shawky, 2014). Interestingly, $\mathrm{Na}^{+}$in the shoots of rice cv. Puntal with AMF-inoculation (C. etunicatum) was similar to that of the uninoculated plants, whereas $\mathrm{Na}^{+}$levels in the root tissues of AMFinoculated plants were higher than control and this involved upregulation of plasma membrane $\mathrm{Na}^{+} / \mathrm{H}^{+}$antiporter (OsSOS1) and high affinity potassium transporter (OsHKT2;1) (Porcel et al., 2016). In addition, it was confirmed that expression of vacuolar $\mathrm{Na}^{+} / \mathrm{H}^{+}$antiporter gene (LeNHX1) in the root tissues of saltstressed tomato was upregulated by AMF (GM) inoculation (He and Huang, 2013).

\section{Soluble Sugar, Free Proline, Osmotic Potential, and Their Relationship}

Sucrose, glucose, and fructose contents in flag leaf tissues were increased when subjected to $150 \mathrm{mM} \mathrm{NaCl}$. Sucrose, glucose and fructose contents in LP plants without AMF under salt stress were peaked at $147.2,115.9$, and $166.7 \mathrm{mg} \mathrm{g}^{-1} \mathrm{DW}$ and enriched by
$62.17,1.19$, and 1.48 folds over the control, respectively (Table 1). Interestingly, fructose in GE-pretreated plants and glucose in GG-pretreated plants of $\mathrm{cv}$. LP exposed to $150 \mathrm{mM} \mathrm{NaCl}$ were increased by 13.59 and 1.86 folds over control, respectively (Table 1). Total soluble sugar in LP without AMF was found to be the maximum (2.02 folds over control) when exposed to salt stress. It was maintained at low levels in AMF-pretreated plants similar to that of salt tolerant rice, Pok (Figure 3A). Free proline in Pok was observed to be similar in both control and salt stressed plants. In contrast, it was significantly high in salt stressed plants of cv. LP by 3.79 folds, LP + GM by 2.19 folds, LP + GG by 3.39 folds, and LP + GE by 5.74 folds over control (Figure 3B). Osmotic potential in salt stressed flag leaf of $\mathrm{cv}$. Pok was maintained, whereas it was significantly declined in LP (1.93 folds over control) and LP + GE (1.37 folds over control). Interestingly, it was retained in LP $+\mathrm{GG}$ and $\mathrm{LP}+\mathrm{GM}$ under $150 \mathrm{mM} \mathrm{NaCl}$ (Figure 3C). Moreover, a negative relationship between free proline content and osmotic potential was demonstrated $\left(R^{2}=0.5879\right.$; Figure $\left.3 \mathrm{D}\right)$.

In rice crop, flag leaf at booting stage is reported to be very sensitive to salt stress (Wankhade et al., 2013). In general, total soluble carbohydrates in the leaf tissues of AMFcolonized plants of trifoliate orange (Zou and $\mathrm{Wu}, 2011$ ) and chickpea (Garg and Bharti, 2018) were upregulated. In trifoliate orange (Poncirus trifoliata), only sucrose was accumulated in the leaves of plants grown under $100 \mathrm{mM} \mathrm{NaCl}$ for 7 weeks, whereas glucose and fructose were unchanged even in the plants inoculated with GM and Glomus versiforme (Zou and 
TABLE 4 | Shoot height, flag leaf length, number of panicles, and panicle length in "Leum Pua" (LP) plants inoculated with AMF (GE; Glomus etunicatum, GG; G. geosporum, and GM; G. mosseae) of rice cv. at booting stage, and subsequently exposed to salt stress conditions for 14 days.

\begin{tabular}{lccccc}
\hline Treatment & $\begin{array}{c}\text { NaCl } \\
(\mathbf{m M})\end{array}$ & $\begin{array}{c}\text { Shoot } \\
\text { height } \\
\mathbf{( c m )}\end{array}$ & $\begin{array}{c}\text { Flag leaf } \\
\text { length } \\
\mathbf{( c m})\end{array}$ & $\begin{array}{c}\text { Number } \\
\text { of } \\
\text { panicles }\end{array}$ & $\begin{array}{c}\text { Panicle } \\
\text { length } \\
\text { (cm) }\end{array}$ \\
\hline Pok & 0 & $126.3 \mathrm{a}$ & $49.5 \mathrm{a}$ & $5.3 \mathrm{a}$ & $27.1 \mathrm{a}$ \\
$\mathrm{LP}$ & 150 & $115.3 \mathrm{a}$ & $48.7 \mathrm{a}$ & $4.2 \mathrm{ab}$ & $26.8 \mathrm{a}$ \\
& 0 & $87.4 \mathrm{~b}$ & $29.7 \mathrm{~b}$ & $3.5 \mathrm{~b}$ & $22.6 \mathrm{ab}$ \\
$\mathrm{LP}+\mathrm{GE}$ & 150 & $82.1 \mathrm{~b}$ & $26.8 \mathrm{~b}$ & $3.0 \mathrm{~b}$ & $18.8 \mathrm{~b}$ \\
& 0 & $86.3 \mathrm{~b}$ & $22.0 \mathrm{~b}$ & $3.0 \mathrm{~b}$ & $23.8 \mathrm{ab}$ \\
$\mathrm{LP}+\mathrm{GG}$ & 150 & $82.3 \mathrm{~b}$ & $20.8 \mathrm{~b}$ & $3.0 \mathrm{~b}$ & $21.1 \mathrm{ab}$ \\
& 0 & $88.2 \mathrm{~b}$ & $27.9 \mathrm{~b}$ & $3.0 \mathrm{~b}$ & $22.4 \mathrm{ab}$ \\
LP + GM & 150 & $84.0 \mathrm{~b}$ & $24.0 \mathrm{~b}$ & $2.3 \mathrm{~b}$ & $21.4 \mathrm{ab}$ \\
& 0 & $88.2 \mathrm{~b}$ & $28.3 \mathrm{~b}$ & $3.2 \mathrm{~b}$ & $24.8 \mathrm{a}$ \\
Significant level & 150 & $87.3 \mathrm{~b}$ & $26.7 \mathrm{~b}$ & $2.5 \mathrm{~b}$ & $21.7 \mathrm{ab}$ \\
\hline
\end{tabular}

Pok: Pokkali, salt tolerant genotype, positive check. ${ }^{* *}$ represents highly significant difference at $p \leq 0.01$. Different letters in each column show significant difference at $p \leq 0.01$ according to Tukey's HSD.

$\mathrm{Wu}, 2011$ ). In contrast, sucrose in chickpea cvs. PBG 5 (salt tolerant) and BG 256 (salt sensitive), inoculated with $R$. intraradices, was declined in response to the degree of salt stress. Glucose and total soluble sugar in salt tolerant PBG 5 (both with or without AMF-inoculation) were gradually increased when subjected to salt stress (Garg and Bharti, 2018). Total soluble sugars in several plants, i.e., wheat, fenugreek, and two legumes (soybean and cluster bean) grown under salt stress were found to vary in accordance to the degree of salt stress, AMF species, and the symbiotic interactions (Evelin et al., 2013; Datta and Kulkarni, 2014a; Talaat and Shawky, 2014). Interestingly, free proline content in salt tolerant $\mathrm{cv}$. Pok was maintained at low levels, whereas it was enriched by 5.74-folds in salt stressed LP with GE inoculation, over the control. An increasing rate of free proline accumulation in the salt stressed plants has been reported in wheat genotypes, tomato cultivars, and mustard plants in relation to salt-tolerant abilities (Hajiboland et al., 2010; Talaat and Shawky, 2014; Sarwat et al., 2016). On the other hand, free proline enrichment varies according to different species of AMF as seen from the differences observed between GM, Glomus fasciculatum (GF), and mixed GM + GF inoculation in Acacia arabica (Datta and Kulkarni, 2014b); R. intraradices, C. etunicatum, and Septoglomus conicatum inoculation in maize (Estrada et al., 2013a); and GM, G. deserticola, and G. gergaria inoculation in wheat (Abdel-Fattah and Asrar, 2012). It was confirmed that the P5CS plays a major role in proline biosynthesis under salt stress in both salt tolerant PBG-5 and salt sensitive CSG9505 genotypes of chickpea (Jahromi et al., 2008; Garg and Baher, 2013). Free proline and total soluble sugars are the major osmolytes in AMF-inoculated plants under salt stress that control the osmotic potential at the cellular level, leading to enhanced salt tolerant ability (Campanelli et al., 2013; Yang et al., 2014; Evelin et al., 2019). Free proline enrichment in the salt stressed plants with AMF inoculation plays a key role as osmotic adjustment (Chun et al., 2018), which confirmed the function as osmolytes by mitigation of $\mathrm{NaCl}$ stress in mustard plant (Sarwat et al., 2016).

\section{Physiological Responses to Salt Stress}

$\mathrm{Chl}_{\mathrm{a}}, \mathrm{Chl}_{\mathrm{b}}$, and $\mathrm{C}_{\mathrm{x}+\mathrm{c}}$ degradation in cv. Pok under salt stress was low as compared to the cv. LP, where these declined by 64.49, 35.39 , and $44.05 \%$ over the control, respectively (Table 2 ). In $\mathrm{LP}+\mathrm{GE}, \mathrm{Chl}_{\mathrm{a}}, \mathrm{Chl}_{\mathrm{b}}$, and $\mathrm{C}_{\mathrm{x}+\mathrm{c}}$ in flag leaf tissues were maintained when subjected to salt stress. In contrast, those parameters in LP + GG and LP + GM under salt stress were sharply dropped by $\geq 50 \%$ (Table 2 ). In addition, TC content in salt stressed plants of $\mathrm{cv}$. Pok was maintained, whereas it was significantly degraded in LP (54.68\% over control), LP + GE (45.39\% over control), LP + GG (60.79\% over control), and LP + GM (60.04\% over control) (Figure 4A). $F_{\mathrm{V}} / \mathrm{F}_{\mathrm{m}}, \Phi_{\mathrm{PSII}}, \mathrm{g}_{\mathrm{s}}$, and $\mathrm{E}$ in the flag leaf of cv. Pok under salt stress were retained, while these were lowered in cV. LP by 25.03, 19.52, 31.03, and 28.89\%, respectively (Table 3 and Figure 4B). However, these parameters were maintained by GE, GG, and GM inoculation even when exposed to salt stress (Table 3 ). $\mathrm{P}_{\mathrm{n}}$ is a very sensitive parameter to salt stress; however, it was maintained in cv. Pok even under salt stress. In AMF inoculated plants, it was significantly declined by $30.10,22.31,29.64$, and $16.75 \%$ over the control in cv. LP, $\mathrm{LP}+\mathrm{GE}, \mathrm{LP}+\mathrm{GG}$, and LP + GM, respectively (Figure 4C). A positive relation between $\Phi_{\mathrm{PSII}}$ and $\mathrm{P}_{\mathrm{n}}$ was also established $\left(R^{2}=0.5994\right.$; Figure 4D).

In the present study, chlorophyll pigments: $\mathrm{Chl}_{\mathrm{a}}, \mathrm{Chl}_{\mathrm{b}}$, and $\mathrm{C}_{\mathrm{x}+\mathrm{c}}$, in GE-inoculated LP plants under salt stress were unchanged, leading to stabilized $\mathrm{F}_{\mathrm{v}} / \mathrm{F}_{\mathrm{m}}, \Phi_{\mathrm{PSII}}$, and $\mathrm{P}_{\mathrm{n}}$, whereas these were degraded by $>50 \%$ over the control in LP without $\mathrm{AMF}$ inoculation. Previously, $\mathrm{Chl}_{\mathrm{a}}$ and $\mathrm{Chl}_{\mathrm{b}}$ in rice crop cv. Puntal with AMF-inoculation (C. etunicatum, isolate EEZ 163) were elevated when compared with non-AMF inoculated crop, both subjected to $150 \mathrm{mM} \mathrm{NaCl}$ for 4 weeks (Porcel et al., 2015). $\mathrm{Chl}_{\mathrm{a}}$ and $\mathrm{Chl}_{\mathrm{b}}$ in AMF-inoculated plants of false wheatgrass (L. chinensis symbiont with GM) and wheat (Triticum aestivum $\mathrm{L}$. cvs. Sids 1 and Giza 168 symbiont with a mixture of Glomus spp.), were alleviated under both normal and salt stressed conditions (Talaat and Shawky, 2014; Lin et al., 2017). Moreover, plantmicrobe interactions are another factor that regulates the salt tolerant abilities in the host plants. For example, $\mathrm{Chl}_{\mathrm{a}}, \mathrm{Chl}_{\mathrm{b}}$, and $\mathrm{C}_{\mathrm{x}+\mathrm{c}}$ in AMF-inoculated wheat grown with GM under saline soil (860 $\mathrm{mg} \mathrm{kg}^{-1} \mathrm{Na}^{+}$) for 8 and 12 weeks were observed to be higher than those in un-inoculated plants and AMF-inoculated plants with $G$. deserticola and G. gergaria (Abdel-Fattah and Asrar, 2012). Consequently, $F_{v} / F_{m}, \Phi_{P S I I}, P_{n}, g_{s}$, and $E$ in AMFinoculated rice cv. Puntal were promoted under both control and salt stressed conditions (Porcel et al., 2015). In maize, $F_{v} / F_{m}$ and $g_{s}$ in plants inoculated with $C$. etunicatum, $R$. intraradices, and Septoglomus claroideum under $100 \mathrm{mM} \mathrm{NaCl}$ for 30 days were alleviated compared to the un-inoculated plants (Estrada et al., 2013b). In rice crop cv. Puntal, efficiency of PSII and $\mathrm{g}_{\mathrm{s}}$ in salt stressed plants (75 and $150 \mathrm{mM} \mathrm{NaCl}$ for 4 weeks) were significantly improved using C. etunicatum isolate EEZ 163 (Porcel et al., 2016). Based on this evidence, it can be suggested 


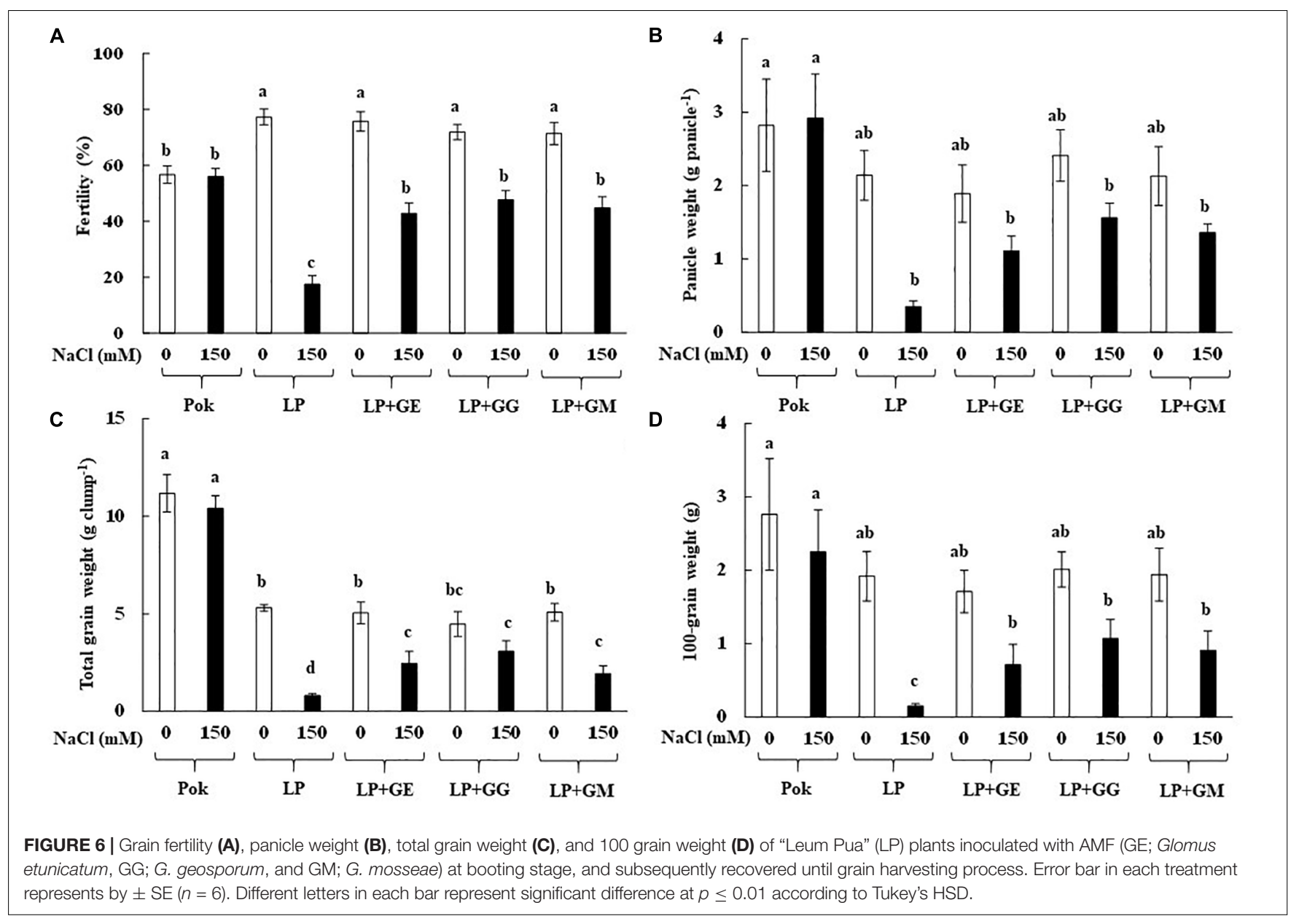

that the regulation of osmolytes and antioxidant activities in AMF-inoculated plant grown under salt stress plays a major role in salt defense mechanisms and reduction of electrolyte leakage at the cellular level (Estrada et al., 2013b). Moreover, the photosynthetic efficiencies in AMF-inoculated plants under salt stress are found to be dependent on type of plant species, genotypic variations, AMF genus/species/strain, degree of salt stress, and their interactions (Wu et al., 2010). A positive relationship between $\Phi_{\text {PSII }}$ and $\mathrm{P}_{\mathrm{n}}$ with a high correlation coefficient has been observed in rice crop $\left(R^{2}=0.691\right.$; Porcel et al., 2015) and black locust $\left(R^{2}=0.789\right.$; Zhu et al., 2014), leading to retain the yield attributes.

\section{Morphological Changes}

Morphological and phenological characters in cvs. Pok and LP under control and salt stress were also observed (Figure 5). Shoot height, flag leaf length, number of panicle, and panicle length were greater in cv. Pok than in cv. LP. Moreover, these parameters were unchanged when plants were subjected to $150 \mathrm{mM} \mathrm{NaCl}$ for 14 days (Table 4). Fertility percentage in cv. Pok under salt stress was unchanged, whereas it was sharply declined by $77.39,43.48,33.68$, and $37.31 \%$ over control in $\mathrm{LP}, \mathrm{LP}+\mathrm{GE}$, LP + GG, and LP + GM, respectively
(Figure 5A). Panicle weight, total grain weight, and 100grain weight were unchanged in salt stressed rice cv. Pok and LP + GG (Figures 6B-D). In contrast, panicle weight, total grain weight, and 100-grain weight in salt stressed rice cv. LP were significantly declined by $83.65,84.91$, and $92.19 \%$, respectively, over the control. It was confirmed that LP is a salt susceptible variety of rice crop. However, yield attributes such as fertility, panicle weight, total grain weight, and 100grain weight in AMF-inoculated plants of LP salt stressed rice showed significant improvement compared with un-inoculated plants (Figure 6).

In the present study, shoot height in LP plants exposed to salt stress was unchanged irrespective of the AMF inoculation. In general, shoot height improves by AMF inoculation, but is subsequently inhibited by salt concentrations (Yano-Melo et al., 2003; Campanelli et al., 2013) and different AMF species (GM, G. deserticola, and G. gergaria) (Abdel-Fattah and Asrar, 2012). In rice crop cv. Puntal, shoot fresh weight and shoot dry weight of AMF-inoculated plants (C. etunicatum) under salt stress (75 and $150 \mathrm{mM} \mathrm{NaCl}$ ) were greater than those in un-inoculated plants (Porcel et al., 2015, 2016). Likewise, number of panicles, panicle weight, grain yield, and 1000-grain weight in rice crop inoculated with AMF (Sebacina vermifera) and subjected to salt stress $\left(3,6\right.$, and $\left.9 \mathrm{dS} \mathrm{m}{ }^{-1} \mathrm{EC}_{\mathrm{e}} \mathrm{NaCl}\right)$ 

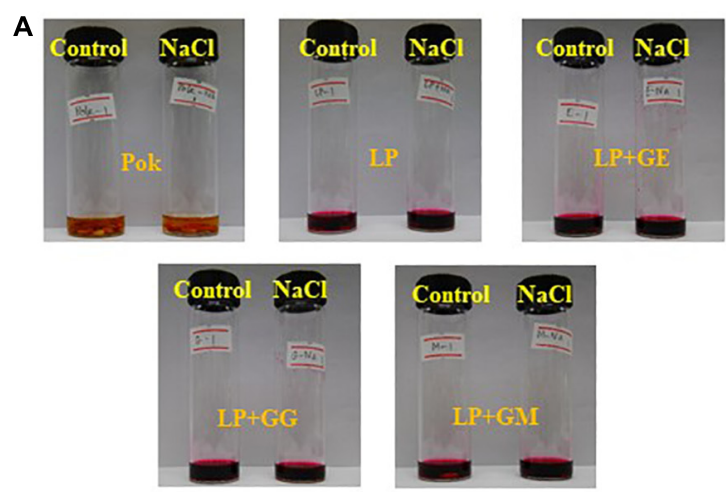

C

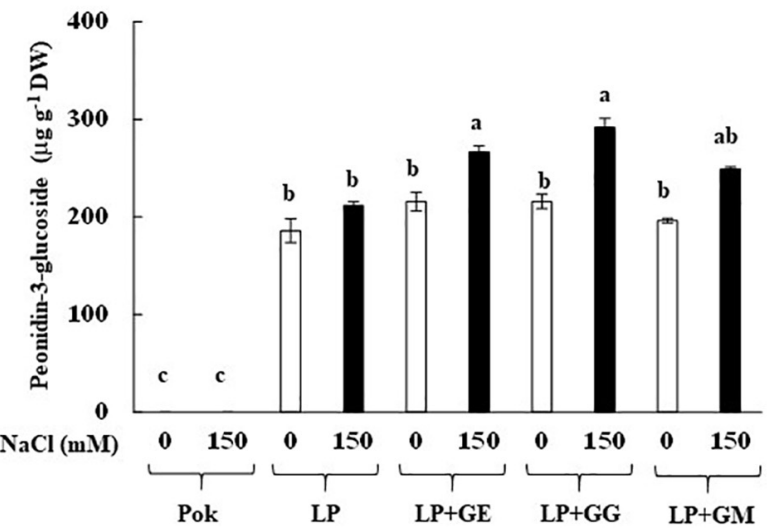

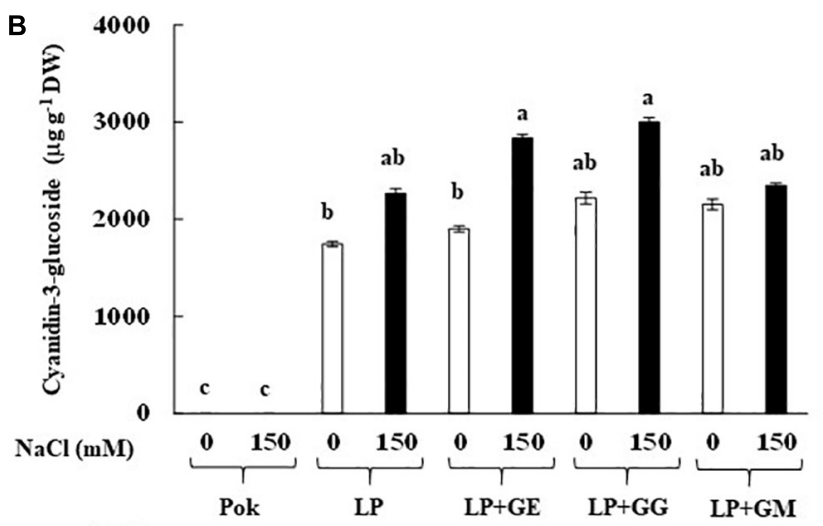

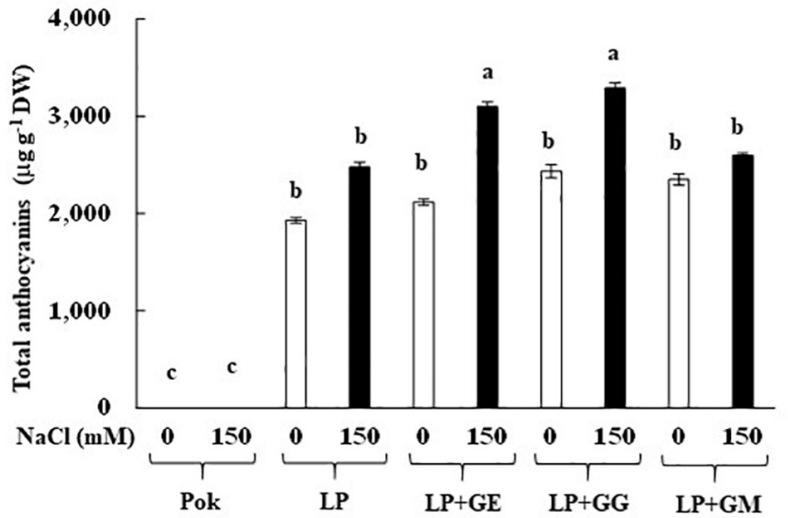

FIGURE 7 | HCl-methanolic extracted solution of rice grain (A), cyanidin-3-glucoside (C3G; B), peonidin-3-glucoside (P3G; C), and total anthocyanins (D) of "Leum Pua" (LP) plants inoculated with AMF (GE; Glomus etunicatum, GG; G. geosporum, and GM; G. mosseae) at booting stage, and subsequently recovered until grain harvesting process. Error bar in each treatment represents by $\pm \mathrm{SE}(n=6)$. Different letters in each bar represent significant difference at $p \leq 0.01$ according to Tukey's HSD.

performed better than that of un-inoculated plants, but again depending on the degree of salt stress (Pirdashti et al., 2012). In wheat cvs. Sids 1 and Giza 168, number of grains per plant and grain yield per plant were significantly improved by AMF-inoculation (mixed Glomus spp.) under salt stress [4.7 and $9.4 \mathrm{dS} \mathrm{m}{ }^{-1}$ (a mixture of $\mathrm{NaCl}, \mathrm{CaCl}_{2}$ and $\mathrm{MgSO}_{4}$ at molar ratio of 2:2:1)] (Talaat and Shawky, 2014). In maize, the salt tolerant abilities (66 and $100 \mathrm{mM} \mathrm{NaCl}$ ) in terms of shoot dry weight of plants subjected to different AMF strains, $R$. intraradices and $C$. etunicatum, were significantly improved than in plants without AMF and those inoculated with S. claroideum (Estrada et al., 2013a,b). Moreover, yield per pot, 1000-grain weight, and grains per ear of AMF-inoculated (Piriformospora indica) barley cvs. Ingrid and Annabell grown under salt stress were greater than that of the un-inoculated plants (Waller et al., 2005).

\section{Anthocyanin Analysis}

Extracted solution of anthocyanins using $1 \% \mathrm{HCl}$ in methanol solvent is presented in Figure 7A. Interestingly, C3G, P3G, and total anthocyanins in cv. Pok were absent, whereas these were accumulated in the pericarp of $\mathrm{cv}$. LP, especially in the AMF-inoculated plants subjected to salt stress (Figures 7B-D). In LP + GE, C3G, P3G, and total anthocyanins in salt stressed pericarp of rice grains were increased by $1.49,1.24$, and 1.47 folds over the control, respectively (Figures 7 B-D). P3G and total anthocyanins in LP + GG under salt stress were significantly increased by 1.35 and $1.35 \%$ over the control, respectively (Figures 7 C,D). In addition, the regulation of $\mathrm{C} 3 \mathrm{G}$ and $\mathrm{P} 3 \mathrm{G}$ chromatogram profiles in LP rice cultivar under salt stress was evidently demonstrated (Figure 8).

Total anthocyanin enrichment in the pericarp of rice grain depends on genotype and the biotic and/or abiotic environmental elicitors. In the present study, anthocyanins in the red pericarp of Pok were absent, whereas two species of anthocyanins, C3G and P3G, were present in cv. LP. In lettuce, anthocyanins in the inner and outer leaves of cv. Maravilla de Verano (MV) were accumulated in higher amounts than Batavia RubiaMurguia (BRM) (Baslam et al., 2011). Anthocyanins were evidently dominated in the stem and whole plant of basil varieties, i.e., Cinnamon, Siam Queen, Sweet Dani, and Red Rubin, whereas these were undetected in the roots (Seagel, 2012). In addition, anthocyanin accumulation in pericarp of rice grain inoculated by $\mathrm{AMF}$ and exposed to $\mathrm{NaCl}$ salt elicitor was clearly observed. In strawberry fruits, C3G, P3G, and pelagonidin-3rutinoside (P3R) were alleviated in plants grown under AMF (Glomus sp.) + Pseudomonas bacteria $+70 \%$ fertilization 
A

\section{Control \\ (0 $\mathrm{mM} \mathrm{NaCl})$}

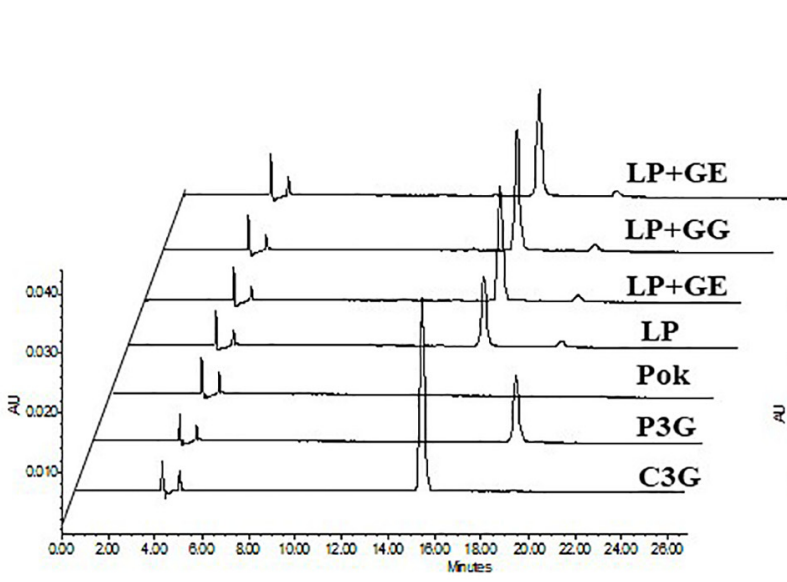

B

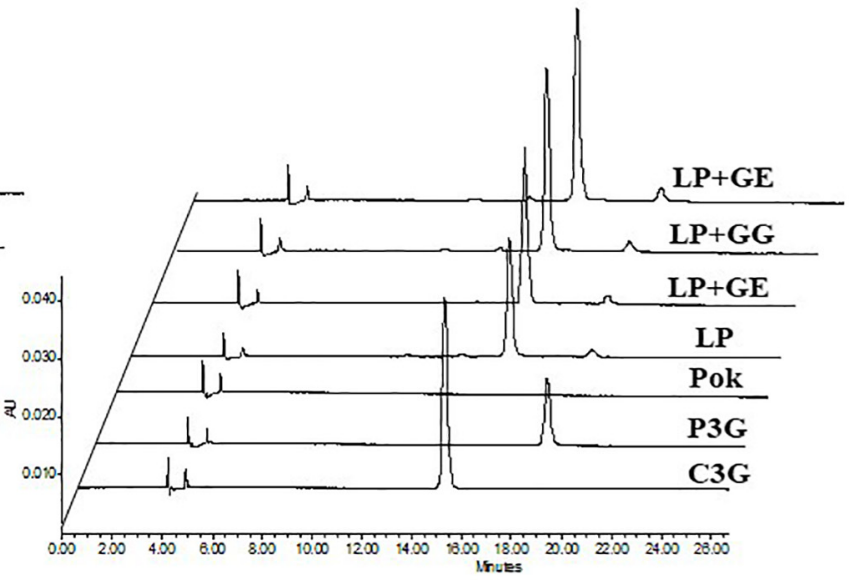

FIGURE 8 | HPLC profiles of cyanidin-3-glucoside (C3G) and peonidin-3-glucoside (P3G) of "Leum Pua" (LP) plants inoculated with AMF (GE; Glomus etunicatum, GG; G. geosporum, and GM; G. mosseae) at booting stage exposed to control (A) and salt stress (B) conditions for 14 days, and subsequently recovered until grain harvesting process.

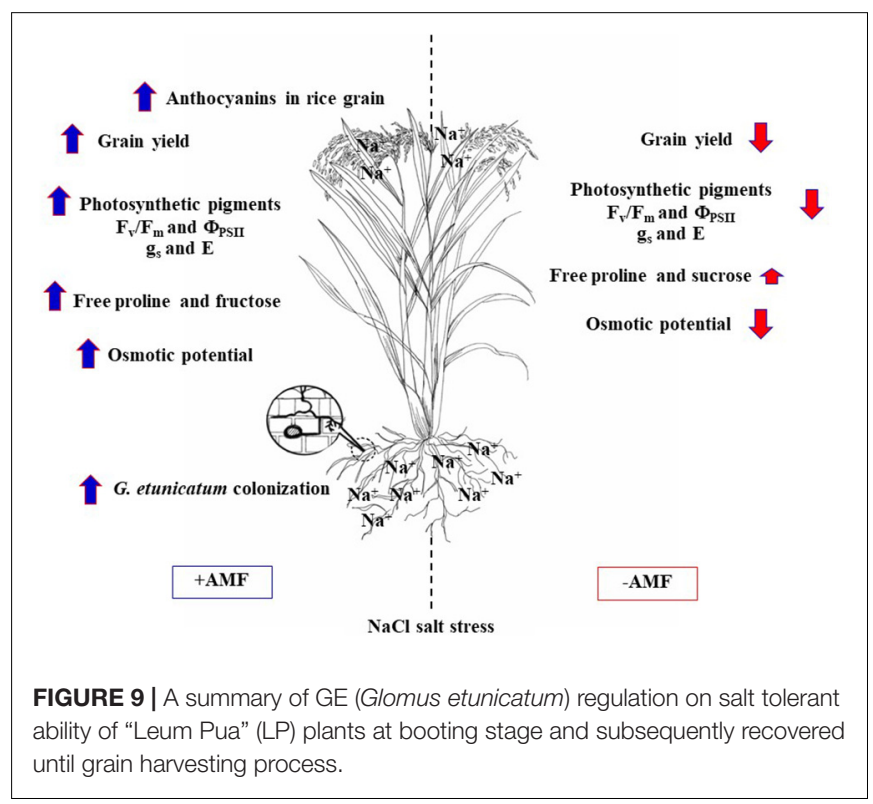

(Lingua et al., 2013). Total anthocyanins were increased in lettuce in AMF (commercial inoculation; mixed G. intraradices and GM) inoculated plants compared to plants without AMF (Baslam et al., 2011). It is possible that $\mathrm{AMF}$ and $\mathrm{NaCl}$ salt may regulate the anthocyanin biosynthesis pathway, via targeting several enzymes, i.e., phenylalanine ammonialyase (PAL), chalcone synthase (CHS), and flavonol synthase (FLS) (Abdallah et al., 2016; Battini et al., 2016). In contrast, proanthocyanidins in the leaves of AMF (Gigaspora albida and Acaulospora longula) inoculated "Aroeira-do-sertão" were unchanged when compared to plants without inoculation (da Silva and Maia, 2018). Likewise, total anthocyanins declined in the leaves of
Cicer arietinum cvs. PGB5 (salt tolerant) and BG256 (salt susceptible), inoculated with AMF ( $R$. intraradices) in response to the degree of $\mathrm{NaCl}$ salt treatments (Garg and Bharti, 2018). Moreover, accumulation of anthocyanins in rice grain varies with the species of Glomus genus, as seen from the greater accumulation of anthocyanins in grains-derived from GG and GE pretreated plants compared to plants with GM inoculation. In lettuce cvs. Cogollos de Tudela, BRM, and Maravia de Verano, GF, G. intraradices, and GM evidently regulated carotenoids (neoxanthin, violaxanthin, antheraxanthin, zeaxanthin, lutein, lactucaxanthin, and $\beta$-carotene) and tocopherols $(\alpha-, \beta$-, and $\gamma$ tocopherols), thereby demonstrating their role as biotic elicitors (Baslam et al., 2013).

\section{CONCLUSION}

Root colonization by GE, GG, and GM was detected irrespective of the salt treatment. GG inoculation leads to high level of phosphorus accumulation in flag leaf of rice crop cv. LP, whereas $\mathrm{Na}^{+}$was trend to increase in salt-treated plants similar to cv. Pok (salt tolerant). Photosynthetic abilities, chlorophyll pigments, $\mathrm{Chl}_{\mathrm{a}}$ fluorescence, and stomatal function in flag leaf of LP inoculated with GE grown under salt stress were stabilized by the production of total soluble sugars and free proline that acted as osmolytes to reduce salt toxicity. Therefore, the yield attributes were maintained, and anthocyanins content was enhanced in the pericarp of rice cv. LP inoculated with GE (Figure 9).

\section{DATA AVAILABILITY STATEMENT}

All datasets for this study are included in the article/Supplementary Material. 


\section{AUTHOR CONTRIBUTIONS}

SC carried out the experiment, data analysis, a draft of manuscript preparation, and played a role as corresponding author. RT analyzed anthocyanins (C3G and P3G) and physiological data. CT did soluble sugar analysis and data analysis. TS assayed free proline and overall growth performances. KP conducted the experiment, AMF-colonization and total phosphorus analysis, and yield attributes. PT played a role as project coordinator and a discussion on manuscript preparation. HS performed a critical reading, comments, suggestion, and grammatical checking before submission.

\section{FUNDING}

The authors would like to sincerely thank The Thailand Research Fund (TRF) for funding support (Grant No. SRI5920201)

\section{REFERENCES}

Abdallah, S. B., Aung, B., Amyot, L., Lalin, I., Lachâal, M., Karray-Bouraoui, N., et al. (2016). Salt stress $(\mathrm{NaCl})$ affects plant growth and branch pathways of carotenoid and flavonoid biosynthesis in Solanum nigrum. Acta Physiol. Plant 38:72. doi: 10.1007/s11738-016-2096-8

Abdel-Fattah, G. M., and Asrar, A. W. A. (2012). Arbuscular mycorrhizal fungal application to improve growth and tolerance of wheat (Triticum aestivum L.) plants grown in saline soil. Acta Physiol. Plant 34, 267-277. doi: 10.1007/ s11738-011-0825-6

Arunin, S., and Pongwichian, P. (2015). Salt-affected soils and management in Thailand. Bull. Soc. Sea Water Sci. 69, 319-325. doi: 10.11457/swsj.69.319

Baslam, M., Esteban, R., García-Plazaola, J. I., and Goicoechea, N. (2013). Effectiveness of arbuscular mycorrhizal fungi (AMF) for inducing the accumulation of major carotenoids, chlorophylls and tocopherol in green and red leaf lettuces. Appl. Microbiol. Biotechnol. 97, 3119-3128. doi: 10.1007/ s00253-012-4526-x

Baslam, M., Pascual, I., Sánchez-Díaz, M., Erro, J., García-Mina, J. M., and Goicoechea, N. (2011). Improvement of nutritional quality of greenhousegrown lettuce by arbuscular mycorrhizal fungi is conditioned by the source of phosphorus nutrition. J. Agric. Food Chem. 59, 11129-11140. doi: 10.1021/ jf202445y

Basu, S., Rabara, R. C., and Negi, S. (2018). AMF: the future prospect for sustainable agriculture. Physiol. Mol. Plant Pathol. 102, 36-45. doi: 10.1016/j.pmpp.2017.11. 007

Bates, L. S., Waldren, R. P., and Teare, I. D. (1973). Rapid determination of free proline for water-stress studies. Plant Soil 39, 205-207. doi: 10.1007/ BF00018060

Battini, F., Bernardi, R., Turrini, A., Agnolucci, M., and Giovannetti, M. (2016). Rhizophagus intraradices or its associated bacteria affect gene expression of key enzymes involved in the rosmarinic acid biosynthetic pathway of basil. Mycorrhiza 26, 699-707. doi: 10.1007/s00572-016-0707-2

Bhattacharjya, S., Bhaduri, D., and Sahu, A. (2018). Arbuscular mycorrhizal fungi: a potential tool for enhancing crop productivity in salt affected soil. Inter. J. Agric. Environ. Biotechnol. 11, 871-880. doi: 10.30954/0974-1712.12.2018.8

Borde, M., Dudhane, M., and Jite, P. (2011). Growth photosynthetic activity and antioxidant responses of mycorrhizal and non-mycorrhizal bajra (Pennisetum glaucum) crop under salinity stress condition. Crop Prot. 30, 265-271. doi: 10.1016/j.cropro.2010.12.010

Brundrett, M., Bougher, N., Dell, B., Grove, T., and Malajczuk, N. (1996). Working with Mycorrhizas in Forestry and Agriculture. ACIAR Monograph 32. Canberra, ACT: Australian Centre for International Agricultural Research, 373.

Campanelli, A., Ruta, C., de Mastro, G., and Morone-Fortunato, I. (2013). The role of arbuscular mycorrhizal fungi in alleviating salt stress in Medicago sativa $\mathrm{L}$. var. icon. Symbiosis 59, 65-76. doi: 10.1007/s13199-012-0191-1 and National Science and Technology Development Agency (NSTDA) for partial support to CT as post-doctoral scholarship and Young Scientist and Technologist Program (YSTP) for partial support to KP.

\section{ACKNOWLEDGMENTS}

Also, we would like to thank Dr. Supatida Aumtong, Maejo University, Chiang Mai, Thailand, for providing three species of Glomus AMF.

\section{SUPPLEMENTARY MATERIAL}

The Supplementary Material for this article can be found online at: https://www.frontiersin.org/articles/10.3389/fpls.2020.00348/ full\#supplementary-material

Chandra, A., Rana, J., and Li, Y. (2001). Separation, identification, quantification, and method validation of anthocyanins in botanical supplement raw materials by HPLC and HPLC-MS. J. Agric. Food Chem. 49, 3515-3521. doi: 10.1021/ jf010389p

Chang, W., Sui, X., Fan, X. X., Jia, T. T., and Song, F. Q. (2018). Arbuscular mycorrhizal symbiosis modulates antioxidant response and ion distribution in salt-stressed Elaeagnus angustifolia seedlings. Front. Microbiol. 9:652. doi: 10.3389/fmicb.2018.00652

Cha-um, S., Supaibulwatana, K., and Kirdmanee, C. (2007). Glycinebetaine accumulation, physiological characterizations and growth efficiency in salttolerant and salt-sensitive lines of indica rice (Oryza sativa L. ssp. indica) in response to salt stress. J. Agron. Crop Sci. 193, 157-166. doi: 10.1111/j.1439037X.2007.00251.x

Chun, S. C., Paramasivan, M., and Chandrasekaran, M. (2018). Proline accumulation influenced by osmotic stress in arbuscular mycorrhizal symbiotic plants. Front. Microbiol. 9:2525. doi: 10.3389/fmicb.2018.02525

da Silva, F. S. B., and Maia, L. C. (2018). Mycorrhization and phosphorus may be an alternative for increasing the production of metabolites in Myracrodruon urundeuva. Theor. Exp. Plant Physiol. 30, 297-302. doi: 10.1007/s40626-0180123-4

Datta, P., and Kulkarni, M. (2014b). Arbuscular mycorrhizal colonization improves growth and biochemical profile in Acacia arabica under salt stress. J. Biosci. Biotechnol. 3, 235-245.

Datta, P., and Kulkarni, M. V. (2014a). Arbuscular mycorrhizal colonization enhances biochemical status and mitigates adverse salt effect on two legumes. Not. Sci. Biol. 6, 381-393. doi: 10.15835/nsb639250

de Leon, T. B., Linscombe, S., and Subudhi, P. K. (2016). Molecular dissection of seedling salinity tolerance in rice (Oryza sativa L.) using a high-density GBS-based SNP linkage map. Rice 9:52. doi: 10.1186/s12284-016-0125-2

Dodd, I. C., and Pérez-Alfocea, F. (2012). Microbial amelioration of crop salinity stress. J. Exp. Bot. 63, 3415-3428. doi: 10.1093/jxb/ers033

Estrada, B., Aroca, R., Barea, J. M., and Ruiz-Lozano, J. M. (2013b). Native arbuscular mycorrhizal fungi isolated from a saline habitat improved maize antioxidant systems and plant tolerance to salinity. Plant Sci. 201, 42-51. doi: 10.1016/j.plantsci.2012.11.009

Estrada, B., Aroca, R., Maathuis, F. J., Barea, J. M., and Ruiz-Lozano, J. M. (2013a). Arbuscular mycorrhizal fungi native from a Mediterranean saline area enhance maize tolerance to salinity through improved ion homeostasis. Plant Cell Environ. 36, 1771-1782. doi: 10.1111/pce.12082

Evelin, H., Devi, T. S., Gupta, S., and Kapoor, R. (2019). Mitigation of salinity stress in plants by arbuscular mycorrhizal symbiosis: current understanding and new challenges. Front. Plant Sci. 10:470. doi: 10.3389/fpls.2019.00470

Evelin, H., Giri, B., and Kapoor, R. (2013). Ultrastructural evidence for AMF mediated salt stress mitigation in Trigonella foenum-graecum. Mycorrhiza 23, 71-86. doi: 10.1007/s00572-012-0449-8 
Evelin, H., and Kapoor, R. (2014). Arbuscular mycorrhizal symbiosis modulates antioxidant response in salt-stressed Trigonella foenum-graecum plants. Mycorrhiza 24, 197-208. doi: 10.1007/s00572-013-0529-4

Evelin, H., Kapoor, R., and Giri, B. (2009). Arbuscular mycorrhizal fungi in alleviation of salt stress: a review. Ann. Bot. 104, 1263-1280. doi: 10.1093/aob/ mcp 251

Garg, N., and Baher, A. (2013). Role of arbuscular mycorrhizal symbiosis in proline biosynthesis and metabolism of Cicer arietinum L. (chickpea) genotypes under salt stress. J. Plant Growth Regul. 32, 767-778. doi: 10.1007/s00344-013-9346-4

Garg, N., and Bharti, A. (2018). Salicylic acid improves arbuscular mycorrhizal symbiosis, and chickpea growth and yield by modulating carbohydrate metabolism under salt stress. Mycorrhiza 28, 727-746. doi: 10.1007/s00572018-0856-6

Gosling, P., Hodge, A., Goodlass, G., and Bending, G. D. (2006). Arbuscular mycorrhizal fungi and organic farming. Agric. Ecosyst. Environ. 113, 17-35. doi: 10.1016/j.agee.2005.09.009

Grattan, S., Zeng, L., Shannon, M., and Roberts, S. (2002). Rice is more sensitive to salinity than previously thought. California Agric. 56, 189-198. doi: 10.3733/ca. v056n06p189

Hajiboland, R., Aliasgharzadeh, N., Laiegh, S. F., and Poschenrieder, C. (2010). Colonization with arbuscular mycorrhizal fungi improves salinity tolerance of tomato (Solanum lycopersicum L.) plants. Plant Soil 331, 313-327. doi: 10.1007/ s11104-009-0255-z

Hameed, A., Dilfuza, E., Abd-Allah, E. F., Hashem, A., Kumar, A., and Ahmad, P. (2014). "Salinity stress and arbuscular mycorrhizal symbiosis in plants," in Use of Microbes for the Alleviation of Soil Stresses, ed. M. Miransari (New York, NY: Springer), 139-159.

He, Z., and Huang, Z. (2013). Expression analysis of LeNHX1 gene in mycorrhizal tomato under salt stress. J. Microbiol. 51, 100-104. doi: 10.1007/s12275-0132423-3

Hossain, G. S., Waditee, R., Hibino, T., Tanaka, Y., and Takabe, T. (2006). Root specific expression of $\mathrm{Na}^{+} / \mathrm{H}^{+}$antiporter gene from Synechocystis sp. PCC6803 confers salt tolerance of tobacco plant. Plant Biotechnol. 23, 275-281. doi: 10.5511/plantbiotechnology.23.275

Jackson, M. L. (1958). Soil Chemical Analysis. Englewood Cliffs, NJ: Prentice Hall.

Jahromi, F., Aroca, R., Porcel, R., and Ruiz-Lozano, J. M. (2008). Influence of salinity on the in vitro development of Glomus intraradices and on the in vivo physiological and molecular responses of mycorrhizal lettuce plants. Microbiol. Ecol. 55, 45-53. doi: 10.1007/s00248-007-9249-7

Karkacier, M., Ebras, M., Uslu, M. K., and Aksu, M. (2003). Comparison of different extraction and detection methods for sugars using amino-bonded phase HPLC. J. Chromatog. Sci. 41, 331-333. doi: 10.1093/chromsci/41.6.331

Kerdphol, R., Sreewongchai, T., Sripichitt, P., Uckarach, S., and Worede, F. (2015). Obtaining a black pericarp and improved aroma using genetic resources from Leum Pua rice. Sci. Asia 41, 93-96. doi: 10.2306/scienceasia1513-1874.2015.41. 093

Khush, G. S. (2005). What it will take to feed 5.0 billion rice consumers in 2030. Plant Mol. Biol. 59, 1-6.

Krishnamoorthy, R., Kim, K., Subramanian, P., Senthilkumar, M., Anandham, R., and Sa, T. (2016). Arbuscular mycorrhizal fungi and associated bacteria isolated from salt-affected soil enhances the tolerance of maize to salinity in coastal reclamation soil. Agric. Ecosyst. Environ. 231, 233-239. doi: 10.1016/j.agee.2016. 05.037

Lanfermeijer, F. C., Koerselman-Kooij, J. W., and Borstlap, A. C. (1991). Osmosensitivity of sucrose uptake by immature pea cotyledons disappears during development. Plant Physiol. 95, 832-838. doi: 10.1104/pp.95.3.832

Latef, A. A. H. A., and Miransari, M. (2014). "The role of arbuscular mycorrhizal fungi in alleviation of salt stress," in Use of Microbes for the Alleviation of Soil Stresses, ed. M. Miransari (New York, NY: Springer), 23-38.

Lichtenthaler, H. K. (1987). Chlorophylls and carotenoids: pigments of photosynthetic biomembranes. Method Enzymol. 148, 350-380.

Lin, J., Wang, Y., Sun, S., Mu, C., and Yan, X. (2017). Effects of arbuscular mycorrhizal fungi on the growth, photosynthesis and photosynthetic pigments of Leymus chinensis seedlings under salt-alkali stress and nitrogen deposition. Sci. Total Environ. 576, 234-241. doi: 10.1016/j.scitotenv.2016.10.091

Lingua, G., Bona, E., Manassero, P., Marsano, F., Todeschini, V., Cantamessa, S., et al. (2013). Arbuscular mycorrhizal fungi and plant growth-promoting pseudomonads increases anthocyanin concentration in strawberry fruits
(Fragaria $\times$ ananassa var. Selva) in conditions of reduced fertilization. Inter. J. Mol. Sci. 14, 16207-16225. doi: 10.3390/ijms140816207

Loggini, B., Scartazza, A., Brugnoli, E., and Navari-Izzo, F. (1999). Antioxidant defense system, pigment composition, and photosynthetic efficiency in two wheat cultivars subjected to drought. Plant Physiol. 119, 1091-1100. doi: 10. 1104/pp.119.3.1091

Maiti, D., Singh, C. V., Variar, M., Mandal, N. P., and Anantha, M. S. (2013). Impact of rainfall pattern on native arbuscular-mycorrhizal activity influencing phosphorus utilization by direct seeded rainfed upland rice (Oryza sativa L.). Proc. Nat. Acad. Sci. U.S.A. 83, 159-162. doi: 10.1007/s40011-012-0132-z

Maiti, D., Variar, M., and Singh, R. K. (2011). Optimizing tillage schedule for maintaining activity of the arbuscular mycorrhizal fungal population in a rainfed upland rice (Oryza sativa L.) agro-ecosystem. Mycorrhiza 21, 167-171. doi: 10.1007/s00572-010-0324-4

Maxwell, K., and Johnson, G. N. (2000). Chlorophyll fluorescence-a practical guide. J. Exp. Bot. 51, 659-668. doi: 10.1093/jexbot/51.345.659

Mbodj, D., Effa-Effa, B., Kane, A., Manneh, B., Gantet, P., Lapaze, L., et al. (2018). Arbuscular mycorrhizal symbiosis in rice: establishment, environmental control and impact on plant growth and resistance to abiotic stresses. Rhizosphere 8, 12-26. doi: 10.1016/j.rhisph.2018.08.003

Muthukumar, T., Bagyaraj, D. J., and Ashwin, R. (2017). "Arbuscular mycorrhizal fungi: Role in alleviating salt stress in crop plants," in Microbes for Plant Stress Management, eds D. J. Bagyaraj and Jamaluddin (New Delhi: New India Publishing Agency), 221-243.

Nakaew, N., and Sungthong, R. (2018). Seed phytochemicals shape the community structures of cultivable actinobacteria-inhabiting plant interiors of Thai pigmented rice. Microbiol. Open 7:e00591. doi: 10.1002/mbo3.591

Panneerselvam, P., Kumar, U., Sugitha, T. C. K., Parameswaran, C., Sahoo, S., Binodh, A. K., et al. (2017). "Arbuscular mycorrhizal fungi (AMF) for sustainable rice production," in Advances in Soil Microbiology: Recent Trends and Future Prospects, Microorganisms for Sustainable, Vol. 4, eds T. Adhya, B. Mishra, K. Annapurna, D. Verma, U. Kumar (Singapore: Springer), 99-126.

Pirdashti, H., Yaghoubian, Y., Goltapeh, E., and Hosseini, S. (2012). Effect of mycorrhiza-like endophyte (Sebacina vermifera) on growth, yield and nutrition of rice (Oryza sativa L.) under salt stress. J. Agric. Technol. 8, 1651-1661.

Pitaktamrong, P., Kingkaew, J., Yooyongwech, S., Cha-um, S., and Phisalaphong, M. (2018). Development of arbuscular mycorrhizal fungi-organic fertilizer pellets encapsulated with alginate film. Eng. J. 22, 65-79. doi: 10.4186/ej.2018. 22.6.65

Piyawanitpong, C., Therdthai, N., and Ratphitagsanti, W. (2018). Effect of precooking and superheated steam treatment on quality of black glutinous rice. J. Food Qual. 2018, 1-9. doi: 10.1155/2018/8496723

Porcel, R., Aroca, R., Azcón, R., and Ruiz-Lozano, J. M. (2016). Regulation of cation transporter genes by the arbuscular mycorrhizal symbiosis in rice plants subjected to salinity suggests improved salt tolerance due to reduced $\mathrm{Na}^{+}$rootto-shoot distribution. Mycorrhiza 26, 673-684. doi: 10.1007/s00572-016-07045

Porcel, R., Aroca, R., and Ruiz-Lozano, J. M. (2012). Salinity stress alleviation using arbuscular mycorrhizal fungi. A review. Agron. Sustain. Dev. 32, 181-200. doi: 10.1007/s13593-011-0029-x

Porcel, R., Redondo-Gómez, S., Mateos-Naranjo, E., Aroca, R., Garcia, R., and Ruiz-Lozano, J. M. (2015). Arbuscular mycorrhizal symbiosis ameliorates the optimum quantum yield of photosystem II and reduces non-photochemical quenching in rice plants subjected to salt stress. J. Plant Physiol. 185, 75-83. doi: 10.1016/j.jplph.2015.07.006

Pornputtapitak, W., Pantakitcharoenkul, J., Panpakdee, R., Teeranachaideekul, V., and Sinchaipanid, N. (2018). Development of $\gamma$-oryzanol rich extract from Leum Pua glutinous rice bran loaded nanostructured lipid carriers for topical delivery. J. Oleo Sci. 67, 125-133. doi: 10.5650/jos.ess17113

Rengasamy, P. (2010). Soil processes affecting crop production in salt-affected soils. Funct. Plant Biol. 37, 613-620. doi: 10.1071/FP09249

Ruiz-Lozano, J. M., and Azcón, R. (2000). Symbiotic efficiency and infectivity of an autochthonous arbuscular mycorrhizal Glomus sp. from saline soils and Glomus deserticola under salinity. Mycorrhiza 10, 137-143. doi: 10.1007/s005720000075

Ruiz-Lozano, J. M., Porcel, R., Azcón, C., and Aroca, R. (2012). Regulation by arbuscular mycorrhizae of the integrated physiological response to salinity in plants: new challenges in physiological and molecular studies. J. Exp. Bot. 63, 4033-4044. doi: 10.1093/jxb/ers126 
Sansenya, S., Hua, Y., and Chumanee, S. (2018). The correlation between 2-acetyl1-pyrroline content, biological compounds and molecular characterization to the aroma intensities of Thai local rice. J. Oleo Sci. 67, 893-904. doi: 10.5650/ jos.ess 17238

Sarwat, M., Hashem, A., Ahanger, M. A., Abd-Allah, E. F., Alqarawi, A. A., Alyemeni, M. N., et al. (2016). Mitigation of $\mathrm{NaCl}$ stress by arbuscular mycorrhizal fungi through the modulation of osmolytes, antioxidants and secondary metabolites in mustard (Brassica juncea L.) plants. Front. Plant Sci. 7:869. doi: 10.3389/fpls.2016.00869

Seagel, C. F. (2012). Phenolic composition of basil plants differentially altered by plant nutrient status and inoculation with mycorrhizal fungi. HortScience 47, 660-671. doi: 10.21273/HORTSCI.47.5.660

Seekhaw, P., Mahatheeranont, S., Sookwong, P., Luangkamin, S., Neonplab, A. N. L., and Puangsombat, P. (2018). Phytochemical constituents of Thai dark purple glutinous rice bran extract [cultivar LuemPua (Oryza sativa L.)]. Chiang Mai J. Sci. 45, 1383-1395.

Senadhira, D., Zapata-Arias, F. J., Gregorio, G. B., Alejar, M. S., de la Cruz, H. C., Padolina, T. F., et al. (2002). Development of the first salt-tolerant rice cultivar through indica/indica anther culture. Field Crop. Res. 76, 103-110. doi: 10.1016/S0378-4290(02)00032-1

Shabala, S. N., Shabala, S. I., Martynenko, A. I., Babourina, O., and Newman, I. A. (1998). Salinity effect on bioelectric activity growth, $\mathrm{Na}^{+}$accumulation and chlorophyll fluorescence of maize leaves: a comparative survey and prospects for screening. Aust. J. Plant Physiol. 25, 609-616. doi: 10.1071/PP97 146

Sheng, M., Tang, M., Chen, H., Yang, B., Zhang, F., and Huang, Y. (2008). Influence of arbuscular mycorrhizae on photosynthesis and water status of maize plants under salt stress. Mycorrhiza 18, 287-296. doi: 10.1007/s00572-008-0180-7

Shrestha, R. P. (2006). Relating soil electrical conductivity to remote sensing and other soil properties for assessing soil salinity in Northeast Thailand. Land Degrad. Dev. 17, 677-689. doi: 10.1002/ldr.752

Talaat, N. B., and Shawky, B. T. (2014). Protective effects of arbuscular mycorrhizal fungi on wheat (Triticum aestivum L.) plants exposed to salinity. Environ. Exp. Bot. 98, 20-31. doi: 10.1016/j.envexpbot.2013.10.005

Tanaka, K., Ohta, K., Haddad, P. R., Fritz, J. S., Lee, K. P., Hasebe, K., et al. (1999). Acid-rain monitoring in East Asia with a portable-type ion-exclusioncation-exchange chromatographic analyzer. J. Chromatog. A 850, 311-317. doi: 10.1016/S0021-9673(99)00286-1

Tisarum, R., Theerawitaya, C., Samphumphuang, T., Phisalaphong, M., Singh, H. P., and Cha-um, S. (2019). Promoting water deficit tolerance and anthocyanin fortification in pigmented rice cultivar (Oryza sativa L. subsp. indica) using arbuscular mycorrhizal fungi inoculation. Physiol. Mol. Biol. Plant. 25, 821-835. doi: 10.1007/s12298-019-00658-4

Vanavichit, A., Kamolsukyeunyong, W., Siangliw, M., Siangliw, J. L., Traprab, S., Ruengphayak, S., et al. (2018). Thai Hom Mali Rice: origin and breeding for subsistence rainfed lowland rice system. Rice 11:20. doi: 10.1186/s12284-0180212-7

Waller, F., Achatz, B., Baltruschat, H., Fodor, J., Becker, K., Fischer, M., et al. (2005). The endophytic fungus Piriformospora indica reprograms barley to salt-stress tolerance, disease resistance, and higher yield. Proc. Nat. Acad. Sci. U.S.A. 102, 13386-13391. doi: 10.1073/pnas.0504423102

Wang, W., Vinocur, B., and Altman, A. (2003). Plant responses to drought, salinity and extreme temperatures: towards genetic engineering for stress tolerance. Planta 218, 1-14. doi: 10.1007/s00425-003-1105-5

Wankhade, S. D., Cornejo, M. J., Mateu-Andrés, I., and Sanz, A. (2013). Morphophysiological variations in response to $\mathrm{NaCl}$ stress during vegetative and reproductive development of rice. Acta Physiol. Plant. 35, 323-333. doi: 10. 1007/s11738-012-1075-y

Wu, Q. S., Zou, Y. N., and He, X. H. (2010). Contributions of arbuscular mycorrhizal fungi to growth, photosynthesis, root morphology and ionic balance of citrus seedlings under salt stress. Acta Physiol. Plant. 32, 297-304. doi: 10.1007/s11738-009-0407-z

Yadav, R. S., Mahatma, M. K., Thirumalaisamy, P. P., Meena, H. N., Bhaduri, D., Arora, S., et al. (2017). "Arbuscular mycorrhizal fungi (AMF) for sustainable soil and plant health in salt-affected soils," in Bioremediation of Salt Affected Soils: An Indian Perspective, eds S. Arora, A. K. Singh, and Y. P. Singh (Cham: Springer), 133-156.

Yang, S. J., Zhang, Z. L., Xue, Y. X., Zhang, Z. F., and Shi, S. Y. (2014). Arbuscular mycorrhizal fungi increase salt tolerance of apple seedlings. Bot. Stud. 55:70. doi: 10.1186/s40529-014-0070-6

Yano-Melo, A. M., Saggin, O. J. Jr., and Maia, L. C. (2003). Tolerance of mycorrhized banana (Musa sp. cv. Pacovan) plantlets to saline stress. Agric. Ecosyst. Environ. 95, 343-348. doi: 10.1016/S0167-8809(02)00044-0

Zeng, L., and Shannon, M. C. (2000). Salinity effects on seedling growth and yield components of rice. Crop Sci. 40, 996-1003. doi: 10.2135/cropsci2000.404996x

Zhang, S., Wang, L., Ma, F., Bloomfield, K. J., Yang, J., and Atkin, O. K. (2014). Is resource allocation and grain yield of rice altered by inoculation with arbuscular mycorrhizal fungi? J. Plant Ecol. 8, 436-448. doi: 10.1093/jpe/rtu025

Zhu, X. Q., Wang, C. Y., Chen, H., and Tang, M. (2014). Effects of arbuscular mycorrhizal fungi on photosynthesis, carbon content, and calorific value of black locust seedlings. Photosynthetica 52, 247-252. doi: 10.1007/s11099-0140031-Z

Zou, Y. N., and Wu, Q. S. (2011). Sodium chloride stress induced changes in leaf osmotic adjustment of trifoliate orange (Poncirus trifoliata) seedlings inoculated with mycorrhizal fungi. Not. Bot. Horti Agrobo. Cluj Napoca 39, 64-69. doi: $10.15835 /$ nbha3926243

Conflict of Interest: The authors declare that the research was conducted in the absence of any commercial or financial relationships that could be construed as a potential conflict of interest.

Copyright (c) 2020 Tisarum, Theerawitaya, Samphumphuang, Polispitak, Thongpoem, Singh and Cha-um. This is an open-access article distributed under the terms of the Creative Commons Attribution License (CC BY). The use, distribution or reproduction in other forums is permitted, provided the original author(s) and the copyright owner(s) are credited and that the original publication in this journal is cited, in accordance with accepted academic practice. No use, distribution or reproduction is permitted which does not comply with these terms. 